\title{
Thule Inuit environmental impacts on Kangeq, southwest Greenland
}

\author{
E. Panagiotakopulu1 ${ }^{1 *}$, J. Edward Schofield ${ }^{2}$, K. Vickers ${ }^{3}$, Kevin J. Edwards, ${ }^{4,5}$ Paul C. \\ Buckland $^{6}$
}

${ }^{1}$ School of GeoSciences, University of Edinburgh, Drummond Street, ${ }^{2}$ EH8 9XP

*Corresponding author - Email address: eva.p@ed.ac.uk

2 Department of Geography and Environment, School of Geosciences, University of

Aberdeen, Elphinstone Road, Aberdeen AB24 3UF, UK

Email address: j.e.schofield@abdn.ac.uk

${ }^{3}$ Department of Archaeology, University of Sheffield, Minalloy House, 10-16 Regent Street, Sheffield, S1 3NJ

Email address: prp02kab@sheffield.ac.uk

${ }^{4}$ Departments of Geography and Environment and Archaeology, School of Geosciences, University of Aberdeen, Elphinstone Road, Aberdeen AB24 3UF, UK

Email address: kevin.edwards@abdn.ac.uk

${ }^{5}$ Scott Polar Research Institute, University of Cambridge, Lensfield Road, Cambridge CB2 1ER, UK

${ }^{6}$ Independent researcher, 20 Den Bank Close, S10 5PA, Sheffield, UK

Email address: paul.buckland@bugscep.com

Declarations of interest: none

\begin{abstract}
Palaeoecological investigations of a rapidly eroding coastal midden and an adjacent peat bog on the island of Kangeq in southwest Greenland have provided new information on environmental change and human impact associated with Thule Inuit occupation.

Palynological and palaeoentomological datasets have been produced through the $14^{\text {th }}$ to the $17^{\text {th }}$ centuries AD. The pollen and sedimentary data provide evidence for peat formation, increased frequency of the northern annual herb Koenigia islandica (Iceland purslane) from the end of the $15^{\text {th }}$ century $\mathrm{AD}$, and a decline in shrub pollen over the same period. These changes are interpreted as local responses to Little Ice Age cooling. No clear signal for human impact on the vegetation was revealed in the pollen record, and there was little macroscopic charcoal recovered from either of the sedimentary contexts that were examined; microscopic charcoal evident in the peat column is probably evidence for domestic fires. The insect remains suggest periodic patterns of disposal on the midden and provide information on natural environments in the vicinity. Fossil fly puparia (Diptera) are associated with decaying animal materials and perhaps indicate waste produced from the skinning of marine mammals and birds as opposed to butchering. The faunas contrast with results from the Saqqaq site of Qeqertasussuk and several Norse farms.
\end{abstract}

\section{Keywords}


palynology, fossil insects, Thule Inuit, Greenland, climate change, human impact

\section{Introduction}

Southwest Greenland has faced increasing levels of human impact during the late Holocene, initially from groups of hunter-fisher Palaeoeskimo - or Palaeo-Inuit (Friesen and Mason 2016) - and subsequently from European (Norse) pastoralists and Thule people (Neoeskimo/NeoInuit) beginning around AD 1000 and 1200 respectively (e.g. Grønnow et al., 1983; Arneborg and Grønnow, 2006). Norse-age and subsequent impacts on the environment have been documented through extensive research. Several studies are available from southwest Greenland that demonstrate a widely repeated palaeoecological footprint for pastoral farming during the Norse settlement period c. AD 1000-1400 (e.g. Fredskild, 1988; Edwards et al., 2011a; Schofield and Edwards, 2011; Buckland et al., 2009; Panagiotakopulu and Buckland, 2013; Panagiotakopulu and Buchan, 2015; Guillemot et al., 2016). Less is known about the effects on the environment arising from the activities of Palaeo- and Neo-Inuit groups in the area. Research has concentrated on animal bones from camp sites (e.g. Grønnow et al., 1983, 2011; Gotfredsen and Møbjerg, 2004; Gotfredsen, 2010) with a view to understanding patterns of hunting, fishing and migration. The classic Palaeo-Inuit (Saqqaq) site of Qeqertasussuk on the island of Disko (see Gronnow, 2017; Meldgaard, 2004), until recently preserved in permafrost, has provided information from a range of palaeoecological proxies (i.e. insects, plants, pollen and animal bones [Böcher and Fredskild, 1993; Meldgaard, ibid.]) and provides an example of the potential of the application of both palynology and fossil insect remains to such archaeological contexts.

The majority of palaeoecological studies that consider the environmental impacts of hunterfisher-gatherer groups at high latitudes have been conducted in woodland (closed-canopy) environments (e.g. Hicks, 1993; Bell et al. 2005; Olsson et al. 2009; Khorasani et al., 2015; Hörnberg et al. 2015; Kamerling et al., 2017) that are very different from those in which the Thule operated in Greenland. Only a small number of palaeoenvironmental studies are available regarding the impacts of Palaeo-Inuit (Saqqaq and Dorset culture) and Neo-Inuit peoples on open arctic landscapes in Greenland and North America. Palynological research has revealed a restricted suite of microfossils that appear to reflect human impact arising from the activity of these cultures (e.g. Böcher and Fredskild 1993; Roy et al. 2015; Ledger 2017). Key 
amongst these appear to be the increased visibility of certain herbaceous taxa (e.g. Montia, Silene, Rumex) reflective of disturbance to local habitats, and elevated levels of charcoal deposited in sedimentary contexts as a likely consequence of the burning of wood for cooking and heating in domestic settings. It seems clear also that the practices of heating and cooking with oil-fuelled lamps, as well as burning of blubber, driftwood and woody materials in exterior hearths, will also have produced their own fossil signatures (e.g. soot and charcoal particles). Nutrient enrichment of soils (e.g. Derry et al. 1999) and freshwater lakes (e.g. Douglas et al. 2004) has also been recorded around Dorset and Thule sites. Insect studies from Saqqaq middens (Böcher and Fredskild 1993; Skidmore, 1996) provided unique information on living conditions and the surrounding environment while research from early Thule culture houses (Dussault et al., 2014) gave information on human and animal ectoparasites and have indicated the potential of this proxy in Greenland. There is also recent insect research from Thule sites in Newfoundland (Dussault et al., 2016) and Yup'ik sites in Alaska (Forbes et al., 2014).

This paper presents pollen, charcoal and fossil insect data from the site of Kangeq, located amongst the coastal skerries west of Nuuk (Fig.1). Kangeq is amongst a suite of archaeological sites in the Arctic that are threatened by coastal erosion, rising sea levels, and the melting of permafrost (Hollesen et al., 2016; Harmsen, 2017), yet former Thule settlements such as this one may hold the key to improving our understanding of past hunter-fisher cultures and their footprint on the Greenlandic landscape. Our research seeks to search the palaeoecological record for evidence of human impact resulting from the activities of Thule culture communities in this area, and to ascertain whether a palynological and palaeoentomological signature for these people can be identified in the fossil record. Where deemed relevant, comment is also passed on evidence for climate change contained within the datasets.

\section{The site}

The former Thule settlement of Kangeq $\left(\sim 64^{\circ} 6^{\prime} \mathrm{N}, 52^{\circ} 3^{\prime} \mathrm{W}\right)$ is located on a small island ( 4 $\mathrm{km}^{2}$ ) of the same name amongst the coastal skerries at the entrance to Godthåbsfjord, $\sim 15 \mathrm{~km}$ southwest of Greenland's capital, Nuuk (Fig. 1). The site was marked on Andreas Gerner's 1731 map of Greenland (Gulløv and Kapel, 1979), and in 1754 it became one of the areas of influence of the Moravian Brethren Mission until its departure from Greenland in 1900. Settlement was initially concentrated around a small coastal inlet up to AD 1930 before 
relocation inland. Excavations by Gulløv (1997) recorded thick midden deposits exposed in coastal sections and five of these have been described (sites A to E in Fig. 1). During the time of these excavations permafrost was noted at site A. Radiocarbon $\left({ }^{14} \mathrm{C}\right)$ dating of the middens suggest that the site was occupied from at least the $14^{\text {th }}$ century AD (Gulløv, 1997). Artefactual evidence from the excavation - two weapon heads thought to be Saqqaq from site A, and a broken lance head, probably Dorset, from site $\mathrm{C}$ - may indicate earlier occupation, perhaps as an overwintering area for hunting groups as a result of its favourable location (Gulløv, ibid). It is unfortunate that most of the artefacts were recovered from the beach and not in situ in the midden deposits. Of particular interest is the angular fragment of Igaliko Sandstone (Fig. 2c). Used to make whetstones by the Norse, this rock was moved from outcrops in the Norse Eastern Settlement to the Western Settlement (cf. Roussell 1941, pp. 251 and 258), perhaps as saleable ballast (cf. Buckland \& Sadler 1990), and its occurrence on a Thule site may reflect nothing more than scavenging from an abandoned farm.

The island of Kangeq was uninhabited at the time of fieldwork (July 2009) although many buildings survive in a state of deterioration. The climate is low-arctic with mean January and July temperatures of $-7.4{ }^{\circ} \mathrm{C}$ and $6.5^{\circ} \mathrm{C}$ respectively, and average annual precipitation totalling $752 \mathrm{~mm}$ (standard climatological normals for the period 1961-90; Cappelen et al. 2001). The relief is low ( $<100 \mathrm{~m}$ a.s.1.), soils are shallow, and much of the bedrock (orthogneiss) over the rounded slopes is exposed. Empetrum (crowberry)-lichen heath is the dominant vegetation community (cf. Fredskild, 1973, 1996). Other common plants recorded on or around the middens included Greenland scurvy-grass (Cochlearia groenlandica), growing abundantly along the seaward edge of the midden, cottongrasses (Eriophorum scheuchzeri and E. angustifolium), alpine bistort (Persicaria vivipara), alpine chickweed (Cerastium alpinum/arcticum), smooth meadow grass (Poa pratensis) and northern willow (Salix arctophila). Bryophytes (Calliergon and Drepanocladus spp.) occur in wet areas. The nomenclature for vascular plants follows Böcher et al. (1968).

\section{Methods}

\subsection{Fieldwork}


During fieldwork, various wooden and stone artefacts from the midden (Site C) were collected, and these have been deposited at the National Museum of Greenland (Fig. 2). A decision was taken to collect peat cores from a mire located near the Thule Inuit houses, and to sample the middens from the face actively being eroded by the sea (Fig. 3).

A Russian corer was used to collect a $50 \mathrm{~cm}$ section from the mire $\left(64^{\circ} 6{ }^{\prime} 26.4^{\prime \prime} \mathrm{N}, 52^{\circ} 2^{\prime} 59.4\right.$ " $\mathrm{W} ; \sim 3 \mathrm{~m}$ a.s.1.) adjacent to the settlement at Kangeq (Fig. 3a) and 50-100 m east of the waste deposits (middens) exposed in coastal sections (cf. Gulløv, 1997). Sediment was collected at depths of $31-81 \mathrm{~cm}$ in the peat profile. Recovery of material above $31 \mathrm{~cm}$ was not possible due to the unconsolidated nature of the wet peat, and compact minerogenic sands at the base of the sequence prevented the collection of any deeper deposits.

The relatively small size of the mire ( $\sim 50 \mathrm{~m}$ in diameter) and its situation within an open (nonwooded) landscape, indicates that the theoretical spatial scale of vegetation reconstruction for this site may be a radius of 800-1000 m (cf. Sugita et al. 1999); however, the basin is enclosed by steep rocky slopes on three sides - to the north, south and east - which may limit much of the pollen input to more local sources (sensu Jacobsen and Bradshaw, 1981). The close proximity to the archaeology should maximise the sensitivity of the environmental archive to impacts arising from human activity in and around the settlement. For further information about pollen representation in southwest Greenland, the reader is referred to Schofield et al. (2007) and Bunting et al. (2013).

An area at the east side of the bay at Kangeq - site C on Gulløv's plan - was sampled for insect remains (Fig. 3b). The sampling concentrated on the eroding face of the section while the rest of the section was not disturbed. An additional 51 sample was taken from an eroding face of the west part of the midden at site A (Fig. 3c), where the permafrost, observed several decades earlier by Gulløv (1997), was found to have completely melted. A sloping rockface at the east end of the section had been utilised to cut a series of largely indecipherable glyphs (Fig. 3d). The age of these remains uncertain, although the extent of weathering and the fact that they had been at least partly overgrown with turf and re-exposed by coastal erosion indicates that they are not recent. The outline of a large human footprint lies partly above the level of interstitial lichen growth on the rock and has only recently (2009) been exposed; a similar rockcut footprint was observed east of the midden, south of the pollen core sampling site. 
Twelve 51 samples (S1-S12) were taken in vertical succession (Fig. 4) from a depth of $120 \mathrm{~cm}$ beneath the topsoil to the base of the organic sediment at $220 \mathrm{~cm}$. The basal sample was taken immediately on the top of a unit of gravel and pebbles. The upper part of the midden section, immediately below the surface, contained $19^{\text {th }}$ century pottery and large numbers of seal bones. Visible in the rest of the midden were seal and bird bones, stone flakes and some wood. At a depth of approximately $100 \mathrm{~cm}$ from the top to $120 \mathrm{~cm}$ were large subangular boulders and smaller stones forming a horizon which could be traced for $5 \mathrm{~m}$ along the section. This may have been a section through a floor, associated with the later seal-hunting phase of the site. One of the stone slabs evident at this depth was used as a datum and sampling took place immediately below it, at $120 \mathrm{~cm}$ below the ground surface. Most of the samples (S1- S6 and $\mathrm{S} 12)$ were $10 \mathrm{~cm}$ in thickness in order to provide adequate organic material (c. 3-5 1) for the fossil insect analyses. From $185 \mathrm{~cm}$ to $210 \mathrm{~cm}$ from the top, it was possible to obtain samples at $5 \mathrm{~cm}$ intervals (S7-S11). No sample was taken at $150-155 \mathrm{~cm}$ as a result of a large stone within the section. S4 was taken from a horizon where a burnt soapstone bowl with a perforated rim and other soapstone fragments, perhaps from the same bowl, were evident (Fig. 2b). S5 and the basal samples (S11 and S12) included large amounts of woodchips, perhaps indicating floor deposits.

\subsection{Laboratory analyses: pollen and associated proxies}

Pollen samples were prepared using standard procedures (Moore et al. 1991) with tablets of Lycopodium clavatum spores added to enable calculation of microfossil concentrations and influx (Stockmarr 1971). Identifications were confirmed using type material held at the University of Aberdeen, and in manuals (Moore et al. 1991; Hedberg 1997). Coprophilous fungal spores were identified using the photographs and notes in van Geel et al. (2003). Microscopic charcoal particles present in pollen sample residues were counted and their sizes measured using a microscope eyepiece graticule. Palynomorph percentages are based upon a total land pollen sum (TLP; trees, dwarf shrubs and heaths, and herbs) exceeding 300 grains. Pollen concentrations fall to extremely low values $\left(<6,000\right.$ grains $\left.\mathrm{cm}^{-3}\right)$ at the centre and top of the core, and therefore results are only presented for the basal half of the profile (i.e. below 55 $\mathrm{cm}$ ). No attempt was made to separate pollen from heaths (the Ericaceae) as many of these (tetrad) pollen types were damaged; these pollen seem likely to represent primarily Empetrum nigrum, given its dominance around the site today (see above). The charcoal data are presented 
as ratios of charcoal to pollen (C:P) concentration (Patterson et al. 1987) and influx. The pollen diagram was divided into local pollen assemblage zones (LPAZs prefixed KAN-) with the assistance of CONISS (Grimm, 1987). Only pollen types within the TLP sum were included within the cluster analysis. Rarefaction analysis (Birks and Line 1992) was performed using the software RStudio. The organic content of samples was estimated using loss-on-ignition (LOI) following combustion at $550^{\circ} \mathrm{C}$.

\subsection{Laboratory analyses: fossil insects}

The thirteen insect samples were sealed in polythene bags in the field and returned to the University of Edinburgh's GeoSciences laboratory for processing. Following the procedure outlined by Coope and Osborne (1968), each sample was disaggregated in warm running water in a clean spouted bucket and poured over into a $300 \mu \mathrm{m}$ sieve. The coarser fraction retained on the sieve was drained of surplus water and returned to the bucket, where paraffin (kerosene) was added and worked into the material. Paraffin flotation was repeated three times for each sample. Sorting was carried out under a low power binocular microscope and the sclerites recovered were stored in 70\% ethanol and distilled water. Identification (Table 1) was carried out using a modern reference collection at the School of GeoSciences, University of Edinburgh and relevant keys (e.g. Böcher, 1988; Böcher et al. 2015). Taxonomy for the Coleoptera follows Böhme (2005), while other groups utilise Böcher (2015). BugsCEP and relevant publications were used for collating habitat data and for the ecological diagram of the beetle assemblages (Buckland and Buckland 2006).

\subsection{Radiocarbon dating and age-depth modelling}

Six plant macrofossil samples - stems, branches and leaves of bryophytes - were selected for AMS radiocarbon $\left({ }^{14} \mathrm{C}\right)$ dating from the pollen core (Table 2). These materials have proved very reliable for constructing chronologies from organic deposits at other locations in southwest Greenland (cf. Edwards et al. 2008). Laboratory processing involved disaggregation of $1 \mathrm{~cm}$ thick core slices in weak $(\sim 2 \%) \mathrm{NaOH}$ followed by transfer of the samples through a $500 \mu \mathrm{m}$ sieve. Moss identifications were confirmed using the key and figures in Smith (1978). An additional five samples of Empetrum nigrum seeds were selected for radiocarbon dating 
during sorting for insect remains; four were taken from the main midden section (as described above), and one from Gulløv's (1997) site A. AMS ${ }^{14} \mathrm{C}$ measurement of plant materials was undertaken at the Scottish Universities Environmental Research Centre (SUERC), East Kilbride (Table 2).

The Bayesian age-depth modelling software Bacon (Blaauw and Christen 2011) was used to construct a chronology for the pollen core. 'Classical' approaches to age-modelling using the software Clam (Blaauw, 2010) were also explored, but the results were deemed less satisfactory. Non-linear options in Clam (i.e. higher polynomial regression, cubic spline and smoothed spline) produced model runs with high numbers of age reversals due to the large degree of overlap between the calibrated ${ }^{14} \mathrm{C}$ dates. Unless otherwise stated, the dates cited in the text in relation to the timing of pollen stratigraphic events are the weighted calibrated means ('best' estimates) taken from Bacon. For the insect samples, the irregular nature of midden deposit accumulation means that age-depth modelling was not deemed appropriate.

\section{Results and interpretation}

\subsection{Chronology}

The six radiocarbon dates returned from the pollen core are contained within a relatively short interval ( 200-400 ${ }^{14} \mathrm{C}$ yr BP) and consequently there is a high degree of overlap following their calibration (Table 2, Fig. 5). This results in clustering of the three lowermost (SUERC29244, -38436 and -38437) and the two uppermost (SUERC-29239 and -29240) dates, but there do not appear to be any outliers. The Bacon age-depth model (Fig. 5) uses all the ${ }^{14} \mathrm{C}$ dates plus the surface (AD 2009) and shows a near-linear rate of sediment accumulation $(\sim 1.6$ $\mathrm{mm} \mathrm{yr}^{-1}$ ) over the last $\sim 500 \mathrm{cal} \mathrm{yr}$. The stratigraphic positions of the radiocarbon dates used in the model are also depicted on the pollen diagram (Fig.6).

The four radiocarbon dates from midden C (Table 2) appear slightly older than those taken from the pollen core, spanning approximately three centuries from c. AD 1300-1600. One date, SUERC-31017 (610 \pm 30 BP), appears out of sequence, i.e. it is older than the preceding samples. This could reflect an 'old carbon error' which might occur, for example, if soil or turf was being added to the midden. Alternatively, this result could simply be an artefact of 
differences in the production of atmospheric ${ }^{14} \mathrm{C}$ at this time; the IntCal13 calibration curve (Reimer et al. 2013) is seen to reverse during the mid-14 th century. Only one ${ }^{14} \mathrm{C}$ sample was

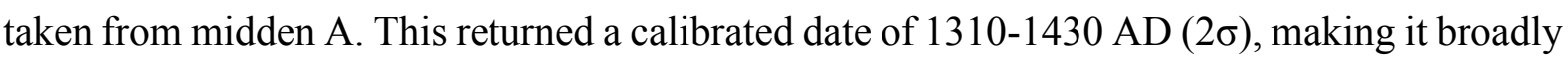
contemporary with much of the dated section of midden $\mathrm{C}$.

\subsection{Lithostratigraphy of the mire}

The deepest sediment recovered during coring was a dark grey, organic-rich, silty sand (81-75 $\mathrm{cm})$. This was overlain by a bryophyte peat $(75-0 \mathrm{~cm})$. The contact between the sand and peat is dated $\sim \mathrm{AD} 1500$. Peat formation may have begun as a consequence of basin infilling (i.e. succession from open water to terrestrial conditions) or as a result of a shift to a cooler and/or wetter climate (these possibilities are discussed below). The elevation of the mire surface ( $\sim 3$ $\mathrm{m}$ a.s.1.) is low, but changes in relative sea-level (RSL) can almost certainly be discounted as the causal factor behind the sedimentary change from sand to peat. Long et al. (2012) report that RSL at sites in western Greenland was rising from $\sim$ AD 1300-1600 - transgression would produce the opposite sedimentary change to that seen here - and mean tidal level was below zero throughout the same period. Furthermore, despite its coastal location, pollen assemblages taken from the sand (described below) do not indicate this to be an inter-tidal deposit; for example, these do not contain signatures for saltmarsh taxa (e.g. Chenopodiaceae).

\subsection{Vegetation history}

The pollen diagram (Fig. 6a, b and c) can be separated into two local pollen assemblage zones (LPAZs KAN-1 and -2). KAN-2 has been further divided into two sub-zones on the basis of minor changes to the pollen assemblages. The age-depth model (Fig. 5) gives a 'best estimate' of $\sim \mathrm{AD} 1470-1620$ for the interval $(80-55 \mathrm{~cm})$ across which palynological data have been generated. The results provide a 'snapshot' of vegetation history for part of the time that the Thule people are considered to have been active at the site (Gulløv 1997).

LPAZ KAN-1 contains samples from the highly-minerogenic basal unit $(81-75 \mathrm{~cm}$; organic content $\sim 10 \%$; dated $\sim$ AD 1470-1500). They are dominated by pollen from Ericaceae (heaths), Salix (willow), Cyperaceae (sedges) and Poaceae (grasses), each registering $\sim 15-20 \%$ TLP. The assemblages appear to reflect the presence of oceanic heath and grassland around the site; a scenario very similar to the modern situation where these floristic types are present in roughly 
equally proportions. The sedge pollen may be largely derived from Eriophorum angustifolium growing on the mire surface, which was very common at the time of sampling.

Pollen from the aquatic plant Hippuris vulgaris (Mare's tail), and microfossils of freshwater algae (Pediastrum), are recorded in trace amounts in some samples. Their values are very low $(<1 \%)$ and thus probably indicate the presence of shallow pools within a mire surface rather than a large expanse of open water. The other notable component $(\sim 10 \%)$ within KAN-1 is Koenigia islandica (Iceland purslane). The significance of this is discussed in detail below.

Low frequencies of Alnus (alder; 5\%) and Betula (birch; 2-3\%) could be largely regional pollen components. Neither genus was recorded in the vegetation survey undertaken on the island at the time of sampling (although this covered only the immediate area around the coring location). The shrubs Alnus crispa and Betula nana are common components of plant communities in adjacent (continental) mainland areas (Fredskild, 1996) and occur widely across sub- and low arctic environments, this being the case both now and in the past (e.g. Fredskild, 1991; Ledger et al. 2016). Occasional grains from the trees Picea (spruce) and Pinus (pine) are almost certainly derived from North America. As both Fredskild (1984) and Rousseau et al. (2006) have noted, varying amounts and sources of long distance transported pollen can relate to climate change and the Kangeq records confirm that the island recruits small amounts of such pollen (cf. Jessen et al., 2011).

Microscopic charcoal particles are common in LPAZ KAN-1. C:P measures $\sim 8-13 \times 10^{7} \mathrm{~cm}^{2}$ grain $^{-1}$, and particle influx is $\sim 4-8 \times 10^{3} \mathrm{~cm}^{2} \mathrm{~cm}^{-2} \mathrm{yr}^{-1}$. These figures for charcoal deposition are broadly similar to values recorded for wetland contexts (mires and ponds) in close proximity to some large Norse farms in southern Greenland; for example, Tasiusaq (Edwards et al., 2008) and Sissarluttoq (Edwards et al., 2011b). This suggests that charcoal particles at Kangeq are largely locally sourced, presumably from domestic fires.

It might be noted that no small spherical particles which might be assumed to represent soot from lamps were detected in pollen preparations. This may not be surprising given that receptacle wicks were trimmed in order to reduce smoke within houses (Hough, 1898; Peary and Ahnighto, 1903), although evidence for soot inhalation is evident from the Greenlandic mummies (Lynnerup, 2015; Hart Hansen and Gulløv 1989) and frequently commented upon. It seems unlikely that taphonomic consideration (e.g. distance) would prevent all such particles 
from reaching the mire, although the large layered and charred lumps of blubber (Fig. 2d) from the midden indicate substantial fires to render down the fat.

The KAN-1/2 zone boundary broadly coincides with the lithostratigraphic change from sand to peat (LOI rising to $>80 \%$ ) at $75 \mathrm{~cm}$ and is dated $\sim \mathrm{AD} 1500$. The frequency of Poaceae pollen remains steady $(\sim 20 \%)$ in LPAZ KAN-2 but several other pollen types show significant change. The most important pattern is a collective decline in shrubs and heaths - reduced from $\sim 50 \%$ to $<30 \%$ - combined with a substantial rise in pollen from Koenigia islandica. Pollen influx values (Fig. 6c) confirm that these represent real (absolute) changes in pollen production, rather than artefacts of the interdependent (percentage) dataset or taphonomic effects resulting from the sedimentary change that is observed at around the same time. There is a further increase in $K$. islandica (to $>60 \%$ ) and a decline in shrub pollen (falling to $10 \%$ ) at the KAN2a/b sub-zone boundary dated $\sim \mathrm{AD} 1540$, and species richness (measured through rarefaction analysis) falls slightly within this sub-zone. These changes occur within the peat unit and are clearly independent of any stratigraphic change. Thus, over a period of approximately 70 years, the palynological data indicate the replacement of shrub and heath vegetation by an herbaceous plant community heavily dominated (almost exclusively so) by K. islandica.

Koenigia islandica is a very small (1-4 cm tall) rapidly-growing annual herb with a northern circumpolar distribution and a low temperature optimum for growth and reproduction (Hedberg, 1997; Heide and Gauslaa, 1999). It is found throughout western Greenland with records being most numerous from the area $\sim 69^{\circ} \mathrm{N}$ around Disko Bay (Fredskild, 1996). The plant occurs over wet gravel or sand (Böcher et al., 1968). Several authors also note a propensity for the species to be found growing amongst wetland mosses, as part of snow-bed communities, along streams, and over solifluction scars (Dahl, 1963; Edwards, 1979; Rune, 2011). The high frequencies of $K$. islandica pollen seen at Kangeq are very unusual. The plant is sensitive to both changes in temperature and precipitation (Meatyard 2001), and rising percentages for this plant - plus the near-disappearance of shrub pollen - seem likely to indicate declining temperatures, and possibly more precipitation falling as snow, and/or greater incidences of late-lying snow which might perpetuate the duration of snow patches (one of the plant's favoured habitats). Locally, at least, heightened soil instability might also be anticipated, largely as a consequence of the removal of the protective cover provided by shrubs. Yet sedimentary evidence to support this idea is difficult to interpret as fine-scale patterns in LOI - a potential proxy for soil erosion - at the time of the $K$. islandica rise are superimposed 
over the profile's only major stratigraphic change (the transition from sands to peat formation). Given the palynological evidence, it thus seems likely that the initiation of peat formation at the site was probably also a consequence of a deteriorating climate, although it remains possible that human disturbance, collecting of shrub vegetation for fuel for instance, may have been part of the cause.

With the exception of two peaks at 71 and $63 \mathrm{~cm}$, the amount of microscopic charcoal deposited on the mire surface during KAN-2 is reduced relative to the previous LPAZ, with influx typically measuring in the range $2-4 \times 10^{3} \mathrm{~cm}^{2} \mathrm{~cm}^{-2} \mathrm{yr}^{-1}$. This seems to indicate fewer incidences of fire, and might be associated with the reduction in shrub cover. The data could reflect a lack of availability of wood for fuel; the severe reduction in shrub cover has already been noted, although the extent to which local people also relied on animal fats in the form of blubber and oil and occasional driftwood for their cooking and heating needs is unknown. Alternatively, the pattern might be caused through a fall in the intensity of use of the site by the Thule culture. This might be explained, for example, if at least some of the Thule people had relocated away from Kangeq. Gulløv (1997, pp. 88-89) notes that one of the sediment units in the midden contains a low frequency of objects and cultural remains, and suggested that this might be explained through a 'partial absence of people'. The precise age of the unit in question is uncertain, but it rests directly on top of a context that has been radiocarbon dated to $\sim$ AD 13001450. Therefore, in terms of timing, the reduction in cultural material in the midden and the decline in microscopic charcoal in the mire are broadly coincident.

\subsection{Insect remains}

The taphonomy of the insect assemblages from Kangeq is difficult to elucidate, both because of the limited taxonomic diversity and as a result of the absence of synanthropic species (Fig. 7). The results indicate no significant changes during midden accumulation and the faunas can therefore be interpreted as a whole. The lack of human ectoparasites, principally lice, contrasts with both the Saqqaq pre-Inuit site at Qeqertasussuk (Panagiotakopulu, unpublished), evidence from the early Thule culture sites of Cape Grinnell and Qaqaitsut (Dussault et al., 2014) and numerous Norse farm sites (e.g. Panagiotakopulu et al., 2007). Lice were also frequently encountered in association with the Thule mummies from Qilakitsoq (Bresciani et al., 1989). The absence of lice in the Kangeq assemblages is not a preservational feature since lice from other animals were present and must relate to the relative proximity of human occupation. The 
beetle faunas are dominated by Micralymma brevilingue. This small rove beetle is common on stoney and sandy beaches, frequently being found under stones near the high water mark, yet also occurring inland (Böcher, 1988; Makarova et al. 2007). It has been recovered in high numbers from the Saqqaq site of Qeqertasussuk (Böcher and Fredskild, 1993), and was present at the Thule site at Assumiut (Böcher, 1998). The remaining beetle faunas from Kangeq are representative of the natural environment. The weevil Dorytomus imbecillus breeds in the catkins of willow, probably in those of Salix arctophila in Greenland (Fjellberg and Böcher, 2006; Böcher, 2015). Hypera diversipunctata appears to be associated with the Caryophyllaceae (Koch, 1992), perhaps Stellaria and Cerastium species at Kangeq, which Morris (2002) suggests are the hosts, although Leguminosae could have been host plants, as recorded by Hansen (1964) in Denmark. Circumpolar in distribution, the weevil is flightless and recorded from scattered localities in southwest Greenland (Böcher, 2015). The species pair, Simplocaria elongata and S. metallica, feed on low bryophytes on stones (Böcher, 1988), and Byrrhus fasciatus is similarly a moss feeder, found in grassy to more rocky habitats throughout southwest Greenland. Colymbetes dolabratus is one of the more common beetles in Greenland. It is present in both coastal and inland locations, lakes and ponds, and is common in stagnant water, whilst the smaller water beetle Hydroporus morio also frequents temporary pools (Böcher ibid). One species, Corticaria linearis (= rubripes), which occurs in two assemblages from Kangeq, is occasionally regarded as being synanthropic (Böcher, 1988) although modern finds in Greenland are restricted to pitfalls set in a variety of litter in grassland and luxuriant vegetation (Böcher, 2015), and Scandinavian records indicate an association with burnt conifers (Kullinsjö, 1999).

The dipterous assemblages from Kangeq (Fig. 8) are dominated by Heleomyza borealis a species which is tolerant of long periods of temperatures below freezing, breeding high up into the Arctic (Worland et al., 2000). It is quite frequent in Greenland where its larvae breed on high protein material, including animal matter, faeces and the dung of omnivorous animals, and may occur below bird cliffs. It prefers shaded or dark areas for breeding and has been found in deposits from Norse farms in large numbers (Panagiotakopulu et al., 2007), to the extent that Skidmore (1996) christened it the "Viking house fly". Its presence at Kangeq is probably associated with decomposing animal matter. In addition other necrophagous species - piophilids, for example Parapiophila vulgaris (=Allopiophila vulgaris), perhaps one of the most widespread members of this family - were recovered in high frequencies. These often occur in association with carrion, particularly where fats and marrow are also 
present (Ozerov, 2000; 2015; Skidmore, 1996). The contrast with Skidmore's results from Norse farms where piophilids are virtually absent (cf. Panagiotakopulu et al., 2007, Fig. 9) is significant (for discussion, see Outram, 1999; 2003).

Other species recovered include the ephydrid Scatella stagnalis, a trophic generalist on green and blue algae (Mathis and Zatwarnicki, 1998; Zack and Foote, 1978), and the scathophagid Scathophaga furcata, a yellow dung fly, which is a common stercoricolous fly and lives on the dung of various mammals, including sheep and dogs (Ferrar, 1987). It is also frequently recorded from human faeces in latrines (Skidmore, 1978). A single specimen of Fannia sp., a genus recovered from dung and carrion, was also found in sample S8. Anthomyiidae, whose habitats range from fungivorous to coprophagous, also occur and some of these may belong to a variety of trophic groups, in particular Fucellia sp., which lives on seaweed and other decaying marine plants (Suwa and Darvas, 1997). Blackflies, ubiquitous in Greenland where mammal or bird blood can be sucked, were represented by the heads of Simulium sp. In addition to flies, fragments of ectoparasites of birds Arctonrnithophilus and Ricinus spp. were also recovered from S10 and S11. These are found on shore birds, Charadriiformes, Actornithophilus cf. uniseriatus and perching birds, Passeriformes, respectively (Smith 2015).

Large, charred blocks of blubber were found in the lower part of the midden (Fig. 2b). These are presumably residues from fires in larger exterior hearths, used to render down seal blubber into more readily usable oil for food and lighting, and in larger quantities for waterproofing umiaks and kayaks. As these activities would probably not have taken place in winter, this evidence indicates that the site was perhaps occupied during other times, at least in the early part of the $14^{\text {th }}$ century. No macroscopic charcoal was found in the midden samples, although the soapstone bowl from S4 (midden C) was probably a cooking vessel, and this provides indirect evidence for burning. Wood, primarily driftwood, or wooden artefacts observed from this and other eroding parts of the Kangeq middens (A and C) were not charred.

\section{Discussion}

The palaeoecological data from Kangeq raises two important discussion points. The first concerns the search for an anthropogenic signature in both the pollen and insect records, and consideration of how the data from Kangeq can further our understanding of the potential environmental impacts arising from Thule Inuit activity on a terrestrial (island) environment. 
The second relates to evidence for climate change. The pollen data contains what appears to be a signal for climatic deterioration dating to the late $15^{\text {th }}$ to early $16^{\text {th }}$ centuries $\mathrm{AD}$.

\subsection{Anthropogenic impacts on vegetation and insect remains}

With the exception of the record for microscopic charcoal, the palynological data generated for Kangeq appears near-indifferent to the close proximity of people. Significant changes to pollen assemblages can all seemingly be explained through natural agencies, particularly a deteriorating climate. Trace amounts of pollen $(<1 \%)$ are present from certain herbs that might potentially be regarded as apophytic (e.g. Montia fontana). Yet the numbers of grains are so low and sporadic, and/or the pollen types in question are so difficult to separate morphologically from a large number of possibilities (e.g. Caryophyllaceae, Brassicaceae), that it would be highly tenuous to link these to human impact with any certainty. Similarly, very few coprophilous fungal spores are recorded - Sordaria-type (HdV-55a) and Sporormiellatype (HdV-113) occur at $<1 \%$ in just two samples. This is perhaps to be expected given that the people under investigation were maritime hunters and that the island was isolated from reindeer migration paths (Meldgaard, 1986), Rangifer tarandus being the only native large herbivore in this region.

The evidence from Kangeq contrasts with that noted by Ledger (2017) for a Yup'ik village in southwest Alaska, where the appearance of spores from coprophilous fungi at the time of settlement is quite striking, yet this was largely attributed to the presence of packs of domesticated dogs on the site. Similarly, Roy et al. (2015) were able to recognise a clear signature for anthropogenic impact in their palynological study from a Thule site at Uivak Point, Labrador. There, people appeared to range quite widely - perhaps up to $1 \mathrm{~km}$ - to harvest plant species for food and other purpose, including wood (spruce) collection. The small size and limited terrestrial resources available to the Thule culture on Kangeq may have been less attractive in this sense, although people were clearly gathering crowberries locally as Empetrum nigrum seeds are found throughout the midden.

The most notable feature of the pollen diagram from Kangeq is the high abundance Koenigia islandica pollen. Changes in the frequency of this pollen type over time seem to be most obviously explained as a consequence of climate change (see Section 5.2 for further details). However, on Svalbard, the modern habitat for this plant includes areas within settlements, as 
the plant is an opportunist that easily occupies areas of fine-grained substrates where and whenever these appear (The Flora of Svalbard, 2018). A possible connection between the increase in $K$. islandica through the $16^{\text {th }}$ century $\mathrm{AD}$, and the activity of Thule people at Kangeq, should therefore not be discounted.

The problem of interpretation of beetle faunas from midden deposits lies in separating autochthonous from allochthonous elements. Whilst the superabundant small rove beetle Micralymma brevilingue probably lived in and on the rocks of the midden and beach, other taxa may reflect structural materials and turf brought to the site. Sclerites of larval Trichoptera, and probably the dytiscid water beetles, Colymbetes dolabratus and Hydroporus morio, would have arrived on site in this manner. The archaeological evidence indicates that Kangeq was an overwintering site (Gulløv 1976; 1997) and M. brevilingue would have been active during the summer in the available niches around the midden during the periods when the site was unoccupied.

The Diptera and ectoparasites reveal patterns of activities associated with the discarding of materials on the midden. The Saqqaq site of Qeqertasussuk (Skidmore, 1996; Panagiotakopulu, unpubl.) has revealed evidence of high numbers of heliophilous calliphorids that indicate fresh meat being thrown on the midden, but Kangeq lacks assemblages signifying the early stages of decay of animal matter. Low winter temperatures could have impacted on the activity of calliphorids (Nuoerteva 1987; Erzinçlioğlu 1986, 2000), delaying the breeding process. The bulk of the fauna from Kangeq, heleomyzids and piophilids, differs in composition both from results from Qeqertasussuk and Norse farms (e.g. Sandnes (Skidmore, 1996; Fig. 9). It indicates later stages in decomposition, while Heleomyza borealis has also been recovered from seal fat and blubber (Panagiotakopulu et al., 2007). The fauna from this particular part of the midden could have been breeding on waste material resulting from the skinning and preparation of seal fur and hides, as opposed to surplus meat from butchering kills. Although ectoparasites actively seek new hosts to feed on, a few individuals may be deposited with the bodies of their hosts and Ricinus and Arctonrnithophilus spp. recovered from the midden indicate the presence of bird skins and feathers from the middens, perhaps for clothing (cf. Nakashima 2002).

The overview of the dipterous assemblages shows a peak in numbers of $H$. borealis for samples $\mathrm{S} 1, \mathrm{~S} 3$ and S11, and much lower numbers for S2, S6, S9, S10 and S12. There is some similarity in the pattern of piophilids, perhaps indicating periodic use of the site or shifting spatial patterns 
of occupation. Gulløv's (1997) research from the site discusses Thule Inuit presence at Kangeq from 1300-1450 AD and this is supported by the new dates and material from the midden. The partial absence of people from horizon 8, site C (Gulløv ibid) is also indicated from insect results. Perhaps the use of the site primarily for overwintering could have been sporadic over several decades as opposed to annual; there is evidence for later use of the site to AD 1635 and beyond.

\subsection{Evidence for climate change: AD 1400-1700 in focus}

A large increase in Koenigia islandica pollen, together with a decline in shrubs and heaths, provides tentative evidence for a deterioration in climate at Kangeq during the late $15^{\text {th }}$ century, with further cooling occurring in the early to mid- $16^{\text {th }}$ century. This is perhaps not unexpected given the timing of these events relative to the conventional period of 'Little Ice Age' (LIA) climate. This is generally accepted as $\sim$ AD 1550-1850 for the Northern Hemisphere (Matthews and Briffa, 2005), although a trend towards colder climate (and cooler summers, in particular) has been noted for the wider interval $\sim A D$ 1250-1850, with the timing and magnitude of cold periods varying between regions (Miller et al., 2010). To examine further and contextualise the evidence from Kangeq, pollen influx data have been plotted against a selected range of highprecision palaeoclimatic datasets from Greenland (Fig. 10).

An increase in precipitation was one of the possibilities proposed to explain the rise to dominance of Koenigia islandica pollen and the beginning of peat formation at Kangeq. Changes in precipitation during the LIA are spatially and temporally more variable, and less well-known, than changes in temperature (Miller et al., 2010). The events described at Kangeq follow shortly after the well-reported strengthening in Northern Hemisphere tropospheric circulation and increase in storminess reflected by elevated sea-salt sodium $(\mathrm{Na}+)$ concentrations in the GISP2 ice core after $\sim$ AD 1400-1420 (Meeker and Mayewski, 2002; Dawson et al. 2007). Yet examination of the accumulation rate (a proxy for snowfall) for the NGRIP ice core (Berggren et al. 2009) reveals little patterning until the mid-17 $7^{\text {th }}$ century, when two extended periods of low values are recorded.

Proxies for temperature are more widely available than those for precipitation, and there is some correspondence with the patterns noted for Kangeq. The rise in Koenigia islandica and decline in shrub pollen occur towards the end of one of the grand minima for sunspot activity 
(the Spörer minimum; AD 1415-1535), as reflected by a rise in the concentration of beryllium$10\left({ }^{10} \mathrm{Be}\right)$ within the NGRIP core (ibid.). 'Winter to winter' deuterium ( $\left.\delta \mathrm{D}\right)$ within GISP2 - a proxy for past air temperature (Barlow 1994) - displays high variability between $\sim$ AD 14501650 , with several periods of extended high and low values. By contrast, the alkenone record for Braya Sø (von Gunton et al., 2016) near Kangerlussuaq clearly indicates a rise in summer temperatures of $\sim 2{ }^{\circ} \mathrm{C}$ around $\sim \mathrm{AD} 1460$ with a subsequent sharp decline of $\sim 3{ }^{\circ} \mathrm{C}$ registered $\sim \mathrm{AD}$ 1525. Low summer temperatures are then sustained until $\sim \mathrm{AD} 1600$. This cold period coincides with minimum values for shrub pollen influx, and peak (albeit erratic) values for $K$. islandica influx, at Kangeq, yet trajectories for the decline in shrubs and rise in K. islandica can be traced back through the earlier period of higher lake temperatures. Thus, although some correspondence can be found between the records, there are also discrepancies. In the case of Kangeq and Braya Sø, this might be explained partly as a consequence of the uncertainties associated with the lake core chronologies, both sites being reliant upon ${ }^{14} \mathrm{C}$ dating (with its inherent errors) rather than the tighter (near) annual control provided by records derived from ice cores.

The sparse nature of information on the modern distribution of Greenland insects precludes any detailed discussion of evidence for climate change from the fossil faunas, although Böcher and Fredskild (1993) were able to suggest slightly warmer summers from the much older Saqqaq site at Qeqertasussuk, southwest of Disko to the north, around 1700 BC (3390 +/- 90 BP) when the site was first settled. The short time spent in the field at Kangeq, in late July 2009, also limited collecting and only two species, the carabids Nebria rufescens (Ström) and Patrobus septentrionis Dej., were collected in three days of pitfall trapping. Despite extensive searching, $M$. brevilingue, so dominant in the fossil assemblages, was not found, although collecting (during August 1983) inland in Ameralla had shown it to still be common and its apparent absence from Kangeq may relate to the collecting period failing to coincide with the emergence of imagines. The faunas, as elsewhere in Greenland, consist of cold stenothermic species which can tolerate the low winter temperatures and are able to take advantage of the short period of summer warmth.

\section{Conclusions}


The palaeoecological data from the Thule site of Kangeq provide new information about the climate, wider environment, and Thule Inuit activity on the island from the $14^{\text {th }}$ to the early $17^{\text {th }}$ centuries $\mathrm{AD}$. The results demonstrate the value of multidisciplinary research in revealing the details of Inuit life in the face of a changing climate. In particular, the following may be highlighted:

- The pollen and sedimentary records from the mire at Kangeq appear to contain a signal for peat formation, a decline in shrubs and heaths, and a rise in the northerly annual herb Koenigia islandica from end of the $15^{\text {th }}$ century AD, with temperatures continuing to drop into the $16^{\text {th }}$ century. There is broad correspondence between these events and patterns displayed by a range of climate proxies collected from ice cores and lakes which indicate falling and/or variable temperatures during the early $16^{\text {th }}$ century.

- The pollen assemblages from Kangeq failed to reveal any clear footprint for Thule impact on the local vegetation, yet the microscopic charcoal record provides very strong evidence for the activities of people, with quantities of charcoal in the pollen samples comparing favourably with those recorded for Norse sites (pastoral farmers) in Greenland. However, there is a lack of macroscopic charcoal in the midden.

- Although the Coleoptera from the middens give evidence for the natural environment and provide limited information about climate, the Diptera from the Kangeq middens, primarily the Heleomyzidae and Piophilidae, indicate the presence of foul materials and disposal of debris, perhaps as part of the process of skinning marine mammals and birds. The presence of Ricinus and Arctonrnithophilus ectoparasites confirms presence of bird skin and bird feathers from the midden.

- The high numbers of species of necrophagous and omnivorous dung flies from particular time periods are an indication of increased disposal of materials on the midden, perhaps associated with patterns of episodic activity.

The middens at Kangeq are currently eroding rapidly and eventually much of this record will be lost to the sea. Palaeoecological research from this and other Inuit middens and structures from Greenland is urgently needed in order to record information on the ecological signatures of the Inuit hunter-fishers before the sites themselves disappear. 


\section{Acknowledgements}

The Leverhulme Trust is thanked for financial support for the project "Footsteps on the Edge of Thule" (Programme Grant F/00 152/Q), directed by Kevin Edwards (University of Aberdeen), Andy Dugmore, Eva Panagiotakopulu (both University of Edinburgh), and Ian Simpson (Stirling University). We are grateful to Andy McMullan, Kirsty Collinge and Ian Simpson for assistance with fieldwork and advice. Gordon Cook is thanked for the provision of radiocarbon dates. Jamie Bowie kindly assisted with the production of diagrams relating to palynological work. The maps and section were drawn by Anastasios Panagiotakopoulos, whose help is warmly acknowledged. Last but not least we are grateful for the helpful comments by the editor and three anonymous reviewers.

\section{References}

Abbott, R.J., Smith, L.C., Milne, R.I., Crawford, R.M.M., Wolff, K., Balfour, J., 2000.

Molecular analysis of plant migration and refugia in the Arctic. Science 289, 1343-1346.

Ægisdóttir, H., pórhallsdóttir, E., 2004. Theories on migration and history of the NorthAtlantic flora: a review. Jökull 54, 1-16.

Álvarez-Solas, J., Ramstein, G., 2011. On the triggering mechanism of Heinrich events. Proceedings of the National Academy of Sciences 108, E1359-E1360.

Arneborg, J, Grønnow, B., 2006. Dynamics of Northern Societies. National Museum, Copenhagen, Denmark.

Barlow, L.K., 1994. Evaluation of seasonal to decadal scale deuterium and deuterium excess signals, GISP2 ice core, Summit, Greenland, A.D. 1270-1985. Ph.D. thesis, University of Colorado, USA.

Bell, T., Macpherson, J.B., Renouf, M.A.P. 2005. Late historic human impact on Bass Pond, Port aux Choix. Newfoundland and Labrador Studies 20, 107-129.

Berggren, A.-M., Beer, J., Possnert, G., Aldahan, A., Kubik, P., Christl, M., Johnsen, S.J., Abreu, J., Vinther, B.M., 2009. A 600-year annual 10Be record from the NGRIP ice core, Greenland. Geophysical Research Letters 36, L11801, doi:10.1029/2009GL038004. 
Birks, H.J.B., Line, J.M., 1992. The use of rarefaction analysis for estimating palynological richness from Quaternary pollen-analytical data. The Holocene 2, 1-10.

Blaauw, M., 2010. Methods and code for 'classical' age-modelling of radiocarbon sequences. Quaternary Geochronology 5, 512-518.

Blaauw, M., Christen, J.A., 2011. Flexible paleoclimate age-depth models using an autoregressive gamma process. Bayesian Analysis 6, 457-474.

Böcher, J., 1989. First record of an interstadial insect from Greenland: Amara alpina (Paykull, 1790) (Coleoptera: Carabidae). Boreas, 18, 1-4.

Böcher, J., 1995. Palaeoentomology of the Kap København Formation, a Plio-Pleistocene sequence in Peary Land, North Greenland. Meddelelser om Grønland, Geoscience, 38, 182.

Böcher, J., 1997. History of the Greenland insect fauna with emphasis on living and fossil beetles. In: Ashworth, A.C., Buckland, P.C., Sadler, J.P. (Eds.) Studies in Quaternary Entomology - An Inordinate Fondness for Insects. Quaternary Proceedings 5, 35-48. Böcher, J., 1998. Insect remains from Asummiut. In: Arneborg, J., Gulløv, H.C. (Eds.) Man, Culture and Environment in Ancient Greenland. Danish National Museum and Danish Polar Centre, Copenhagen, pp. 133-136.

Böcher, J., 1988. The Coleoptera of Greenland. Meddelelser om Grønland - Bioscience 26, 1100.

Böcher, J., 2002. Insekter og andre smådyr i Grønlands fjeld og ferskvand. Nuuk and Copenhagen, Atuagkat.

Böcher, J.., Fredskild, B., 1993. Plant and arthropod remains from the palaeo-Eskimo site on Qeqertasussuk, west Greenland. Meddleelser om Grønland 30, 1-35.

Böcher, T.W., Holmer, K., Jakobsen, K., 1968. The flora of Greenland. P. Haase and Son, Copenhagen.

Böcher, J. 2015. Coleoptera. In, Böcher, J., Kristensen, N. P., Pape, T. \& Vilhelmsen, L. B. (Eds.) The Greenland Entomofauna: An Identification Manual of Insects, Spiders and Their Allies. Fauna Entomologica Scandinavica 44. Leiden, Brill, pp. 259-292.

Böhme, J., 2005. Die Käfer Mitteleuropas. K. Katalog (Faunistiche Übersicht) (2nd ed.). Munich, Spektrum Academic.

Bresciani, J., Haarlov, N., Nansen, P. \& Moller, G., 1983. Head louse (Pediculus humanus subsp. capitis de Geer) from mummified corpses of Greenlanders, A.D. $1460(+50)$. Acta Entomologica Fennica, 42, 24-27. 
Buckland, P.C., Edwards, K.J., Panagiotakopulu, E., Schofield, J.E., 2009. Palaeoecological and historical evidence for manuring and irrigation at Garðar (Igaliku), Norse Eastern Settlement, Greenland. The Holocene 19, 105-116.

Buckland, P. I., Buckland, P. C., 2006. Bugs Coleopteran Ecology Package (Versions:

BugsCEP v7.56; Bugsdata v7.11; BugsMCR v2.0; BugStats v1.2) www.bugscep.com. Last accessed: 21 January 2018.

Buckland, P.C., Sadler, J., 1990. Ballast and Building Stone: a Discussion. In: Parsons, D., (Ed.) Stone quarrying and building in England AD 43-1525. Chichester, Philimore pp. 114125.

Bunting, M.J., Schofield, J.E., Edwards, K.J. 2013. Estimates of relative pollen productivity (RPP) for selected taxa from southern Greenland: a pragmatic solution. Review of Palaeobotany and Palynology 190, 66-74.

Cappelen, J., Jørgensen, B.V., Laursen, E.V., Stannius, L.S., Thomsen, R.S., 2001. The observed climate of Greenland, 1958-99 - with climatological standard normals, 1961-90. Danish Meteorological Institute Technical Report 00-18. DMI, Copenhagen.

Coope, G.R., Osborne, P.J., 1968. Report on the Coleopterous Fauna of the Roman Well at Barnsley Park, Gloucestershire. Transactions of the Bristol and Gloucestershire Archaeological Society 86, 84-87.

Dahl, E., 1963. On the heat exchange of a wet vegetation surface and the ecology of Koenigia islandica. Oikos 14, 190-211.

D’Andrea, W.J., Huang, Y., Fritz, S.C., Anderson, N.J., 2011. Abrupt Holocene climate change as an important factor for human migration in west Greenland. Proceedings of the National Academy of Sciences of the USA 108, 9765-9769.

Dawson, A.G., Hickey, K., Mayewski, P.A., Nesje, A., 2007. Greenland (GISP2) ice core and historical indicators of complex North Atlantic climate changes during the fourteenth century. The Holocene 17, 427-434.

Douglas, M. S. V., Smol, J.P., Savelle, J.M., Blais, J.M., 2004. Prehistoric Inuit whalers affected Arctic freshwater ecosystems. Proceedings of the National Academy of Sciences $101,1613-1617$.

Dussault, F., Bain, A., Lemoine, G., 2014. Early Thule winter houses: an archaeoentomological analysis. Arctic Anthropology 51, 101-117.

Dussault, F., Bell, T.J., Grimes, V., 2017. Archaeoentomological Perspectives on Dorset Occupations in Newfoundland: A Case Study from the Site of Phillip's Garden. Arctic 69(1) $1-15$. 
Edwards, K.J., 1979. Earliest fossil evidence for Koenigia islandica - middle-Devensian interstadial pollen from Lewis, Scotland. Journal of Biogeography 6, 375-377.

Edwards, K.J., Schofield, J.E., Mauquoy, D., 2008. High resolution paleoenvironmental and chronological investigations of Norse landnám at Tasiusaq, Eastern Settlement, Greenland. Quaternary Research 69, 1-15.

Edwards, K.J., Erlendsson, E. and Schofield, J.E., 2011a. Is there a Norse 'footprint' in North Atlantic pollen records? In: Sigmundsson, S., Holt, A., Sigurðsson, G., Ólafsson, G., Vésteinsson, O., (Eds.) Viking settlements and society: papers from the Sixteenth Viking Congress, Reykjavík and Reykholt, 16-23 August 2009. Hið íslenska fornleifafélag and University of Iceland Press, Reykjavík, pp. 65-82.

Edwards, K.J., Schofield, J.E., Kirby, J.R., Cook, G.T., 2011b. Problematic but promising ponds? Palaeoenvironmental evidence from the Norse Eastern Settlement of Greenland. Journal of Quaternary Science 26, 854-865.

Erzinçlioğlu, Z., 1996. Blowflies. Naturalists' handbooks 23: Slough: Richmond Publishing Co. Ltd.

Erzinçlioğlu, Z., 2000. Maggots, Men and Murder: Memories and reflections of a Forensic Entomologist. Harley Books.

Ferrar, P., 1987. A Guide to the Breeding Habits and Immature Stages of the Diptera Cyclorrhapha. Entomonograph 8, 907pp.

Forbes, V., Britton, K., Knecht, R., 2014. Preliminary archaeoentomological analyses of permafrost-preserved cultural layers from the pre-contact Yup'ik Eskimo site of Nunalleq, Alaska: implications, potential and methodological considerations. Environmental Archaeology 14, 158-167.

Fredskild, B., 1973. Studies in the vegetational history of Greenland. Meddelelser om Grønland 198, 1-245.

Fredskild, B., 1984. Holocene palaeo-winds and climatic changes in West Greenland as indicated by long-distance transported and local pollen in lake sediments. In: Mörner, N.-A. (Ed.) Climatic changes on a yearly to millennial basis. D.Reidel, Dordtrecht, pp. 163-171. Fredskild, B., 1988. Agriculture in a marginal area - south Greenland from the Norse landnám (985 A.D.) to the present (1985 A.D.). In: Birks, H.H., Birks, H.J.B., Kaland, P.E., Moe, D. (Eds.) The cultural landscape - past, present and future. Cambridge University Press, Cambridge, pp. 381-393.

Fredskild, B., 1991. The genus Betula in Greenland - Holocene history, present distribution and synecology. Nordic Journal of Botany 11, 393-412. 
Fredskild, B., 1996. A phytogeographical study of the vascular plants of west Greenland $\left(62^{\circ} 20^{\prime}-74^{\circ} 00^{\prime} \mathrm{N}\right)$. Meddelelser om Grønland, Bioscience 45, 1-157.

Friesen, T.M. \& Mason, O.K. (Eds) 2016. The Oxford Handbook of the Prehistoric Arctic. Oxford University Press, Oxford.

Grimm, E.C., 1987. CONISS: a FORTRAN 77 program for stratigraphically constrained cluster analysis by the method of incremental sum of squares. Comput Geosci 13:13-35

Gulløv, H.C., 1976. Kangeq. Et uddrag af Gronlands historie. - Gronland 4: 97-116.

Gulløv, H.C., Kapel, H., 1979. Haabetz Colonie 1721-1728. A Historical-Archaeological Investigation of the Danish-Norwegian Colonization of Greenland. National Museum of Denmark, Copenhagen.

Gulløv, H.C., 1997. From Middle Ages to colonial times: archaeological and ethnohistorical studies of the Thule culture in south west Greenland 1300-1800 AD. Meddelelser om Grønland, Man and Society 23, 1-501.

Gotfredsen, A.B., 2010. Faunal remains from the Wollaston Forland-Clavering ø region, northeast Greenland. Thule culture subsistence in a High Arctic polynya and ice-edge habitat. Danish Journal of Geography 110(2): 175-200.

Gotfredsen, A.B., Møbjerg, T., 2004. Nipisat - a Saqqaq Culture Site in Sisimiut Central West Greenland. Meddelelser om Grønland, Man and Society 31, 1-243.

Grønnow B., Gulløv H.C., Jakobsen H.B., Gotfredsen, A.B., Kauffmann, L.H., Kroon, A., Bjarke, J., Pedersen, T., Sørensen M., 2011. At the edge: High Arctic Walrus hunters during the Little Ice Age. Antiquity 85(309), 960-977.

Grønnow B., Meldgaard M., Nielsen J.B., 1983. Aasivissuit-the Great Summer Camp. Archaeological, ethnographical and zoo-archaeological studies of a caribou-hunting site in west Greenland. Meddelelser om Grønland, Man and Society 5: 1-96.

Guillemot, T., Bichet, V., Gauthier, E., Zocatelli, R., Massa, C. \& Richard, H., 2016. Environmental responses of past and recent agropastoral activities on south Greenlandic ecosystems through molecular biomarkers. The Holocene 26, 783-795.

Hansen, V., 1964. Fortegnelse over Danmarks biller (Coleoptera). - Entomologiske Meddelelser 33: 1-507.

Harmsen, H., (2017) Letter from Greenland. Archaeology 1-4.

Hart Hansen, J.P., Gulløv, H.C., 1989. The mummies from Qilakitsoq: Eskimos in the 15th century. Meddelelser om Grønland: Man and Society 12, 1-192.

Hedberg, O., 1997. The genus Koenigia L. emend. Hedberg (Polygonaceae). Botanical Journal of the Linnean Society 124, 295-330. 
Heide, O.M., Gauslaa, Y., 1999. Developmental strategies of Koenigia islandica, a higharctic annual plant. Ecography 22, 637-642.

Hicks, S., 1993. Pollen evidence of localised impact on the vegetation of northernmost Finland by hunter-gatherers. Vegetation History and Archaeobotany 2, 137-144.

Hollesen, J., Matthiesen, H., Møller, A.B., Westergaard-Nielsen, A., Elberling, B., 2016. Climate change and the loss of organic archaeological deposits in the Arctic. Nature Scientific Reports 6, Article number: 28690. doi:10.1038/srep28690

Hough, W., 1898. The origin and range of the Eskimo lamp. American Anthropologist A11 (4), 116-122.

Hörnberg G., Josefsson T., Bergman I., Liedgren Lars, Östlund L., 2015. Indications of Shifting Cultivation West of the Lapland Border: Multifaceted Land Use in Northernmost Sweden since AD 800. The Holocene 25, 989-1001.

Jedlička, L., Stloukalová, V., 1997. Family Simuliidae. In: Papp L., Darvas B., (Eds.), Contribution to a Manual of Palaearctic Diptera. Volume 2: Nematocera and Lower Brachycera. Science Herald, Budapest, Hungary, pp. 331-347.

Jessen, C.A., Solignac, S., Nørgaard-Pedersen, N., Mikkelsen, N., Kuijpers, A., Seidenkrantz, M-S., 2011. Exotic pollen as an indicator of variable atmospheric circulation over the Labrador Sea region during the mid to late Holocene. Journal of Quaternary Science 26, 286-296.

Kamerling, I.M., Schofield, J.E., Edwards, K.J., Aronsson, K-Å., 2017. High-resolution palynology reveals land use history of a Sami renvall in northern Sweden. Vegetation History and Archaeobotany 26, 369-388.

Khorasani, S., Panagiotakopulu, E., Engelmark, R. and Ralston, I., 2015. Late Holocene beetle assemblages and environmental change in Gammelhemmet, northern Sweden. Boreas, 44 (2), 368-382.

Koch, K., 1992. Die Käfer Mitteleuropas. Ökologie 3. Goecke and Evers, Krefeld.

Kullingsjö, O., 1999. The role of Corticaria rubripes (Coleoptera: Lathridiidae) in dispersal of fungi to burned forest. Växtskyddsnotiser, 4 .

Ledger, P.M., 2017. Are circumpolar hunter-gatherers visible in the palaeoenviromental record? Pollen-analytical evidence from Nunalleq, southwestern Alaska. The Holocene doi:110.1177/0959683617729447.

Ledger, P.M., Edwards, K.J., Schofield, J.E., 2016. The biogeographical status of Alnus crispa (Ait.) Pursch in sub-Arctic southern Greenland: do pollen records indicate local populations during the past 1500 years? Polar Biology 39, 433-441. 
Long, A.J., Woodroffe, S.A., Milne, G.A., Bryant, C.L., Simpson, M.J.R., Wake, L.M., 2012. Relative sea-level change in Greenland during the last 700 yrs and ice sheet response to the Little Ice Age. Earth and Planetary Science Letters 315-316, 76-85.

Lynnerup, N., 2015. The Thule Inuit Mummies from Greenland. The Anatomical Record 298 (6) 1001-6.

McGovern, T., 2000. The Demise of Norse Greenland. In: Fitzhugh, W., Ward, E. (Eds.), Vikings: The North Atlantic Saga, Smithsonian Institution Press (London): 327- 339. Mathis, W.N., Zatwarnicki, T., 1998. Family Ephydridae. In: Papp L., Darvas B., (Eds.), Contribution to a Manual of Palaearctic Diptera. Volume 3: Higher Brachycera. Science Herald, Budapest, Hungary, pp. 535-570.

Matthews, J.A., Briffa, K.R., 2005. The 'Little Ice Age': re-evaluation of an evolving concept. Geografiska Annaler 87A, 17-36.

Meatyard, B. 2001. Koenigia islandica (Iceland purslane): a case study of a potential indicator of climate change in the UK. In: Visconti, G., Beniston, M., Iannorelli, E.D., Barba, D. (Eds) Global change and protected areas, Kluwer Academic Publishers, New York, pp. 209-217.

Meeker, L.D, Mayewski, P.A. (2002) A 1400-year high-resolution record of atmospheric circulation over the North Atlantic and Asia. The Holocene 12, 257-266.

Meldgaard, M., 2004. Ancient Harp Seal Hunters of Disko

Bay. Subsistence and Settlement at the Saqqaq Culture Site Qeqertasussuk. (2400-1400 BC), West Greenland. Meddelelser om Grønland 330, Man and Society 30, 1-189.

Merz, B., Haenni, J.P., 2000. Morphology and terminology of adult

Diptera In: Papp, L., Darvas, B. (Eds.), Contributions to a manual of Palaearctic Diptera. Volume 1. Science Herald, Budapest, Hungary, pp.21-51.

Miller, G.H., Brigham-Grette, J., Alley, R.B., et al., 2010 Temperature and precipitation history of the Arctic. Quaternary Science Reviews 29, 1679-1715.

Moore, P.D., Webb, J.A., Collinson, M.E., 1991. Pollen analysis, 2nd edn. Blackwell, Oxford.

Morris, M.G., 2002. True Weevils (Part 1) Coleoptera: Curculionidae (Subfamilies Raymondionyminae to Smicronychinae). Handbooks for the identification of British insects 3, 17b. Royal Entomological Society \& Field Studies Council, London.

Nakashima, D., 2002. Inuit Women's Knowledge of Bird Skins and its Application in Clothing Construction, Sanikiluaq, Nunavut. Material Culture Review / Revue de la culture matérielle. Available at: 
https://journals.lib.unb.ca/index.php/MCR/article/view/17936/22031/. Last accessed: 18 January 2018.

NOAA, 2017. National Oceanic and Atmospheric Administration National Centers for Environmental Information. https://www.ncdc.noaa.gov/. Last accessed: 21 November 2017.

Nuorteva, P., 1987. Empty puparia of Phormia terraenovae R.-D. (Diptera: Calliphoridae) as forensic indicators. Annales Entomologici Fennici 33:53-56.

Olsson, F., Gaiilard, M.-J., Lemdahl, G., Greisman, A., Lanos, P., Marguerie, D., Marcoux, N., Skoglund, P., Wäglind, J., 2009. A continuous record of fire covering the last 10,500 calendar years from southern Sweden -The role of climate and human activities. Palaeogeography, Palaeoclimatology, Palaeoecology 291, 128-141.

Outram, A.K., 1999. A comparison of paleo-eskimo and medieval Norse bone fat exploitation in western Greenland. Arctic Anthropology 36, 103-117.

Outram, A.K., 2003. Comparing levels of subsistence stress amongst Norse settlers in Iceland and Greenland using levels of bone fat exploitation as an indicator. Environmental Archaeology 8, 119-128.

Ozerov, A.L., 2000. Piophilidae. In: Papp L., Darvas B. (Eds.), Contributions to a Manual of Palaearctic Diptera. Appendix Volume. Science Herald, Budapest, pp. 355-365.

Ozerov, A.L., 2015. Piophilidae (Cheese skippers). In: Böcher, J., Kristensen, N.P., Pape, T. Vilhelmsen, L.B. (Eds.), The Greenland Entomofauna: An Identification Manual of Insects, Spiders and Their Allies. Fauna Entomologica Scandinavica 44, Leiden, Brill, pp. 603-606.

Panagiotakopulu, E. Buchan, A., 2015. Present and Norse hayfields in southwest Greenland Insect assemblages, taphonomy and biogeography. The Holocene 25, 6, 921-931.

Panagiotakopulu, E., Buckland, P.C., 2013. Late Holocene Insect faunas from Tasiusaq, South West Greenland. Boreas 42, 1, 160-172.

Panagiotakopulu, E. Skidmore, P., Buckland P.C., 2007. Fossil insect evidence for the end of the Western Settlement in Greenland. Naturwissenschaften 94, 300-306.

Pape, T., 2015. Calliphoridae, Oestridae, Tachinidae. In: Böcher J., Kristensen, N.P., Pape T., Vilhelmsen, L. (Eds). The Greenland Entomofauna: An Identification Manual of Insects Spiders and Their Allies, 658-665. Fauna Entomologica Scandinavica 44. Leiden, Brill. Peary, J.D., Peary A.M., 1903. Children of the Arctic. F.A. Stokes Company, New York. Reimer, P.J., Bard, E., Bayliss, A., et al. 2013. IntCal13 and Marine13 radiocarbon age calibration curves 0-50,000 years cal BP. Radiocarbon 55, 1869-1887. 
Rousseau, D.-D, Schevin, P., Duzer, D., Cambon, G., Ferrier, J., Jolly, D., Poulsen, U., 2006.

New evidence of long distance pollen transport to southern Greenland in late spring. Review of Palaeobotany and Palynology 141, 277-286.

Roussell, A., 1941. Farms and churches of the medieval Norse settlement in Greenland. Meddelelser om Grønland 89, 1.

Roy, N., Woollett, J., Bhiry, N., 2015. Palaeoecological perspectives on landscape history and anthropogenic impacts at Uivak Point, Labrador, since AD 1400. The Holocene 25, 1 14.

Rune, F., 2011. Wild flowers of Greenland. Gyldenlund Publishing, Hillerød.

Schofield, J.E., Edwards, K.J. 2011. Grazing impacts and woodland management in Eriksfjord: Betula, coprophilous fungi, and the Norse settlement of Greenland. Vegetation History and Archaeobotany 20, 181-197.

Schofield, J.E., Edwards, K.J., McMullen, J.A. (2007) Modern pollen-vegetation relationships in subarctic southern Greenland and the interpretation of fossil pollen data from the Norse landnám. Journal of Biogeography 34, 473-488.

Skidmore. P., 1978. Dung. In: Stubbs, A. and Chandler, P. (Eds. A Dipterist's Handbook, Amateur Entomologist 15, 73-79.

Skidmore, P., 1996. A Dipterological perspective on the Holocene history of the North Atlantic area. Ph.D. thesis, University of Sheffield, UK.

Smith, A.J.E. 1978. The moss flora of Britain and Ireland. Cambridge University Press, Cambridge.

Smith, V.S., 2015. Lice: the parasitic Psocodea. In: Böcher, J., Kristensen, N.P., Pape, T. Vilhelmsen, L.B. (Eds.), The Greenland Entomofauna: An Identification Manual of Insects, Spiders and Their Allies. Fauna Entomologica Scandinavica 44, Leiden, Brill, pp. 89-98.

Stockmarr, J., 1971. Tablets with spores used in absolute pollen analysis. Pollen et Spores 13, 615-621.

Stuiver, P.J., Reimer, P.J., Reimer, R.W., 2017. Calib 7.1 [WWW program]. http://calib.org. Last accessed: 21 November 2017.

Sugita, S., Gaillard, M.-J., Broström, A. 1999. Landscape openness and pollen records: a simulation approach. The Holocene 9, 409-421.

Suwa, M., Darvas, B. 1998. Family Anthomyiidae. In: Papp L., Darvas B. (Eds.), Contribution to a Manual of Palaearctic Diptera. Volume 3. Science Publisher, Budapest, pp. 571-616.

The Flora of Svalbard, 2018. http://svalbardflora.no/. Last accessed: 25 July 2018. 
van Geel, B., Buurman, J., Brinkkemper, O., Schelvis, J., Aptroot, A., van Reenen, G., Hakbijl, T., 2003. Environmental reconstruction of a Roman Period settlement site in Uitgeest (The Netherlands), with special reference to coprophilous fungi. Journal of Archaeological Science 30, 873-883.

von Gunton, L., D’Andrea, W.J., Bradley, R.S., Huang, Y., 2016. Proxy-to-proxy calibration: increasing the temporal resolution of quantitative climate reconstructions. Scientific

Reports 2, 609, doi:10.1038/srep00609.

Worland, M.R., Block, W., Grubor-Lajsic, G., 2000. Survival of Heleomyza borealis

(Diptera, Heleomyzidae) larvae to $-60^{\circ} \mathrm{C}$. Physiological Entomology $25,1-5$.

Zack, R.S., Foote, B.A. Jr, 1978. Utilization of Algal Monocultures by Larvae of Scatella stagnalis. Environmental Entomology 7 (4), 509-511.

\section{Figure and table captions}

Fig. 1. (a) Location of Kangeq and (b) of the middens examined in this and previous studies (redrawn from Gulløv, 1997).

Fig. 2. Artefacts recovered from the Kangeq midden: (a) wooden objects; (b) burnt soapstone bowl with perforated rim and fragments, ulu handle, etc (c) bone slider, Chalcedony flake and fragment of Igaliko Sandstone from the midden (d). charred block of blubber from the lower part of the midden. The artefacts are lodged with the Greenland National Museum.

Fig. 3. Photographs of the sampled areas: (a) View west over the former Thule settlement of Kangeq. The pollen core was collected from the mire in the centre of the photograph (the gold star marks the coring location). This is closely adjacent to the sampled middens (indicated by the arrows) that are exposed in open sections around the small marine inlet. (b) Midden C, Kangeq. (c) Midden C, Kangeq, close up of section sampled for insect remains. (d) Midden A, Kangeq, sampled for insect remains. (e) Features pecked into a sloping rock surface at Kangeq to the east of midden $\mathrm{C}$. The apparent pecking accentuates natural features in rock. 
Fig. 4. Stratigraphic column through Midden C. The position of AMS ${ }^{14} \mathrm{C}$ dates $(2 \sigma$ calibrated ranges) is shown. Sampling started at $120 \mathrm{~cm}$ below the modern ground surface, immediately beneath a large stone slab. A burnt soapstone jar was recovered from c. 133-165 $\mathrm{cm}$, within S4.

Fig. 5. Bacon age-depth model for the Kangeq pollen core. The model was run using 17 sections of $5 \mathrm{~cm}$ thickness with the prior for deposition time (acc.mean) adjusted to $5 \mathrm{yr} \mathrm{cm}^{-1}$ from the standard value of $20 \mathrm{yr} \mathrm{cm}^{-1}$ (this being informed as optimal for model outcomes after trial runs). The model interpolates between the uppermost ${ }^{14} \mathrm{C}$ date and the modern surface $(0-31 \mathrm{~cm})$, and extrapolates between the lowermost date and the base of the pollen analysed sequence $(75-80 \mathrm{~cm})$. The other model settings do not vary from their default positions. The calibrated ${ }^{14} \mathrm{C}$ dates used in the model are depicted in blue. The model results are shown in grey with darker shading indicating more likely calendar ages. Grey-stippled lines mark the $95 \%$ confidence limits on the model, and the yellow line shows the single 'best' model based on the weighted mean age for each depth.

Fig. 6. Pollen diagrams for Kangeq. (a) Percentage pollen diagram for selected shrubs, heaths and herbs. Long-distance transported pollen types (Pinus and Picea) are also shown, as are loss-on-ignition values. + indicates $<1 \%$ TLP. Pollen types under $1 \%$ and present in fewer than three samples have been omitted. Calendar ages are given for the base and top of the profile, and for pollen zones boundaries. These dates are the weighted means taken from the age-depth model (Fig. 5). (b) Percentage pollen diagram (continued) for selected herbs, aquatics and spores. Species richness (rarefaction) and microscopic charcoal (C:P, charcoal to pollen ratio) are also presented. (c) Pollen influx diagram for Kangeq (selected taxa only). Charcoal influx figures are also presented.

Fig. 7. Ecological diagram of fossil beetles, Coleoptera, remains present in Midden $\mathrm{C}$ at Kangeq redrawn from BugsCEP (Buckland and Buckland 2006). A logarithmic transformation of the data, using Bugstats (Abundance weighted; Raw) was used in order to compensate for a logarithmic response of species abundances to environmental variables. For detailed information on taxa present see Table 1.

Fig. 8. Ecological diagram of fossil flies, Diptera, and ectoparasite remains recovered from Midden $\mathrm{C}$ at Kangeq. For detailed information on taxa present see Table 1. 
Fig. 9. Comparison of presence of Heleomyzidae and Piophilidae from pre-Inuit, Thule and Norse sites. The vertical axis of the diagram represents Minimum Numbers of Individuals and the horizontal axis overall results for these two taxa from Thule Kangeq, Saqqaq Qeqertasussuk and Norse Sandnes (Skidmore 1996).

Fig. 10. Selected climatic proxies from ice cores (GISP2 and NGRIP) for the period AD 1400-1700 plotted against palynological results from Kangeq. Data for the ice cores are taken from the National Oceanic and Atmospheric Administration (NOAA, 2017) database and have been smoothed using a 10-year running average. Dashed red lines indicate the mean values over the 300 -yr period of interest. Key to individual graphs: (a) NGRIP ${ }^{10} \mathrm{Be}$ concentration (Berggren et al. 2009) and timings of grand solar mimima; (b) NGRIP accumulation rate (ibid.); (c) GISP2 $\delta$ D values, 'winter to winter' measurements (e.g. Barlow 1994); (d) alkenone-based summer temperature reconstruction from Braya Sø near Kangerlussuaq, western Greenland (von Gunton et al. 2016); (e) Koenigia islandica pollen influx at Kangeq (this paper); (f) cumulative pollen influx from shrubs and heaths at Kangeq (this paper).

Table 1

Insect remains from the Kangeq midden. ${ }^{14} \mathrm{C}$ dates and Minimum Numbers of Individuals (MNIs) are indicated on the table.

Table 2

Radiocarbon dates from the pollen core and the middens sampled for insects. Calibration was performed using IntCal13 (Reimer et al. 2013) and the software Calib 7.1 (Stuiver et al. 2017). 
(a)

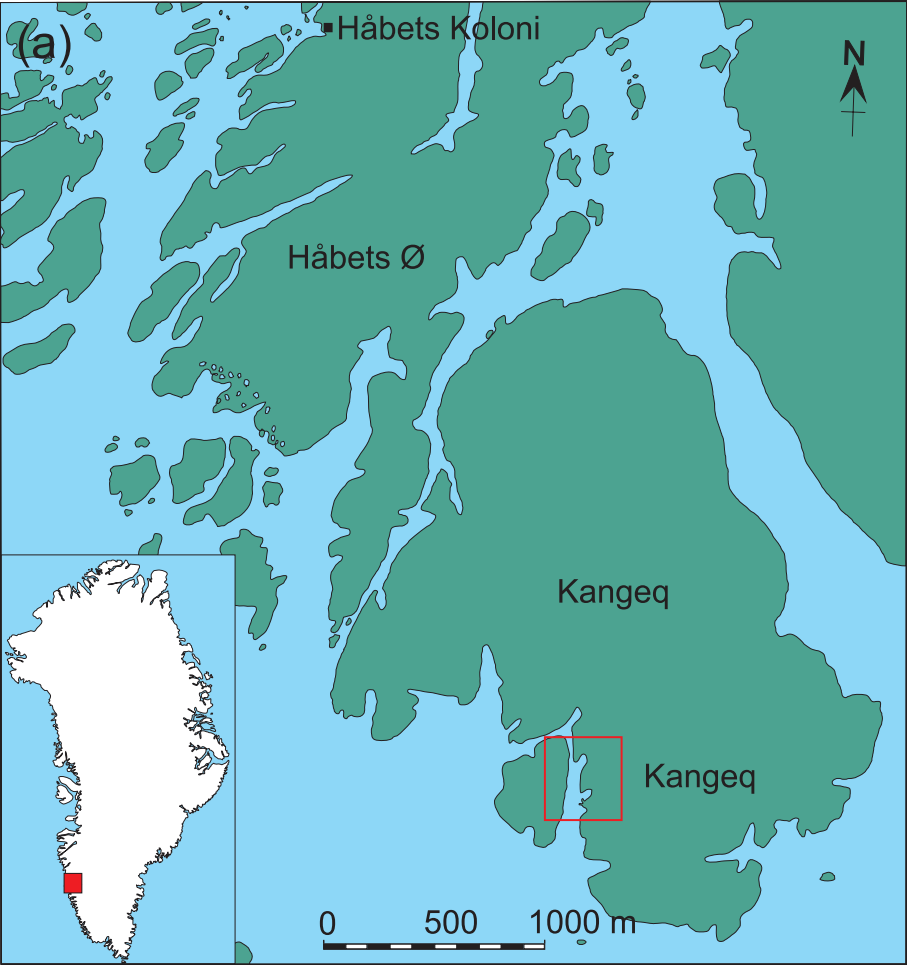

(h) $30 \mathrm{~m}$

$40 \mathrm{~m}$

High Water Mark $\mathbb{N}$ Middens \& Ruins $0 \quad 50 \mathrm{~m}$
$20 m$ $10 \mathrm{~m}^{20}$

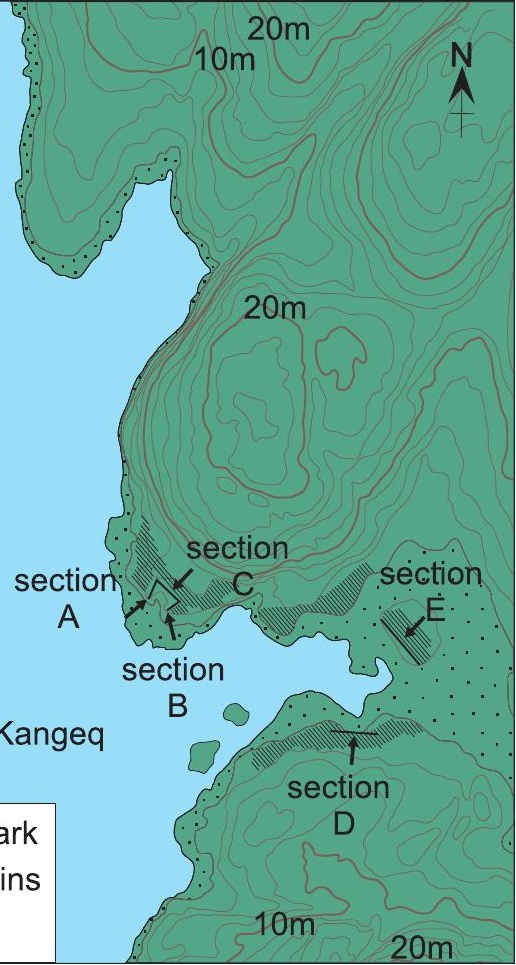




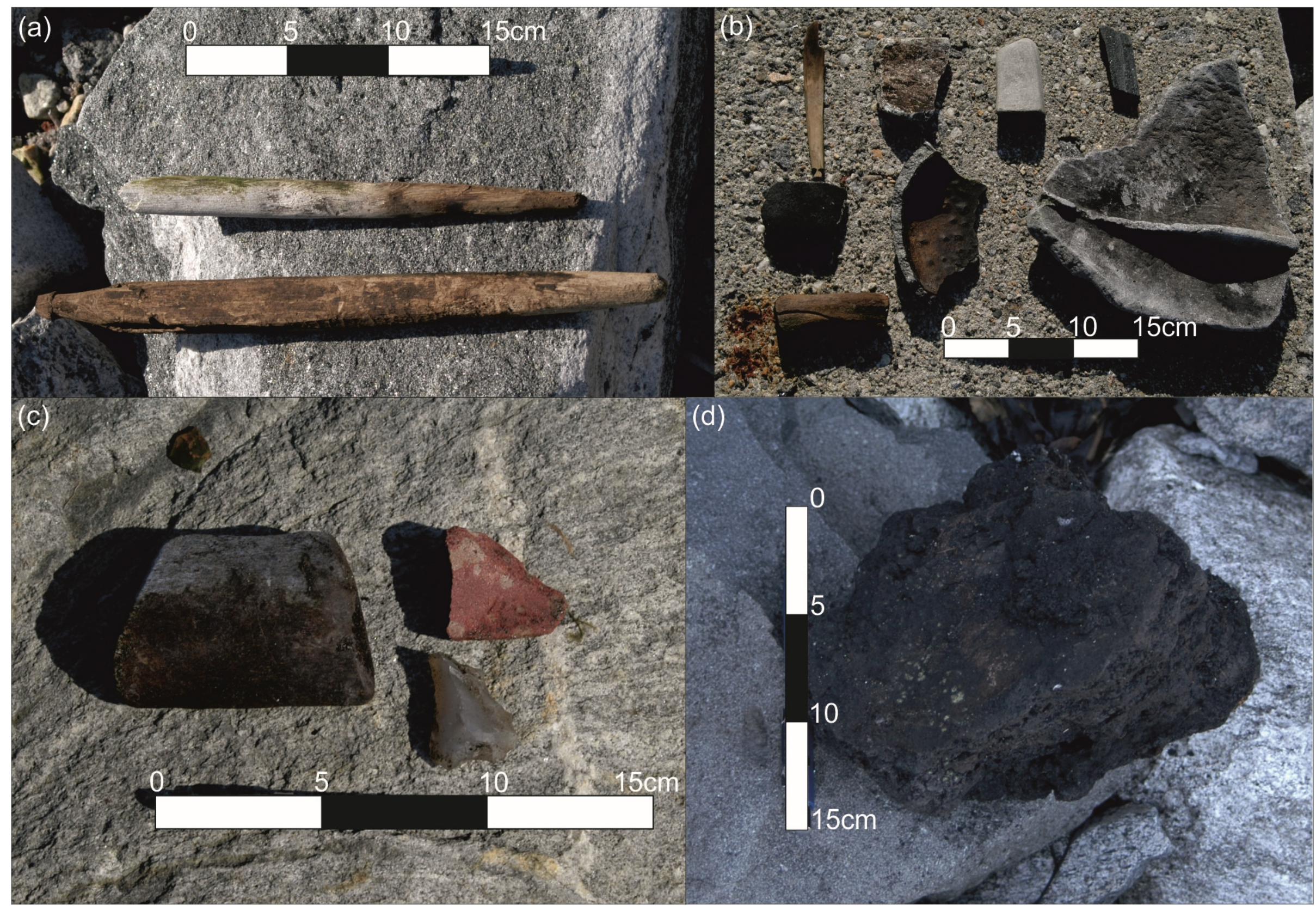




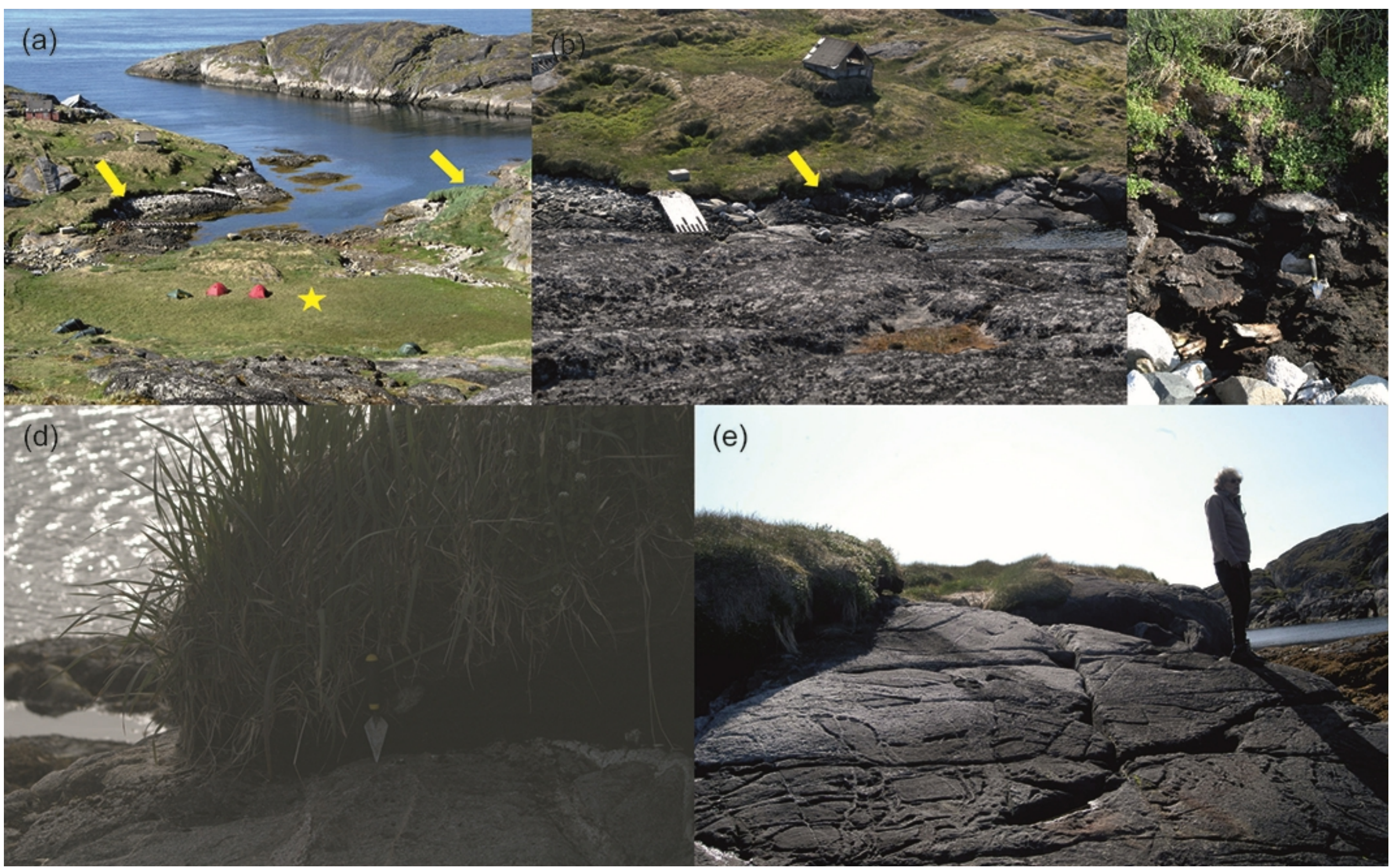



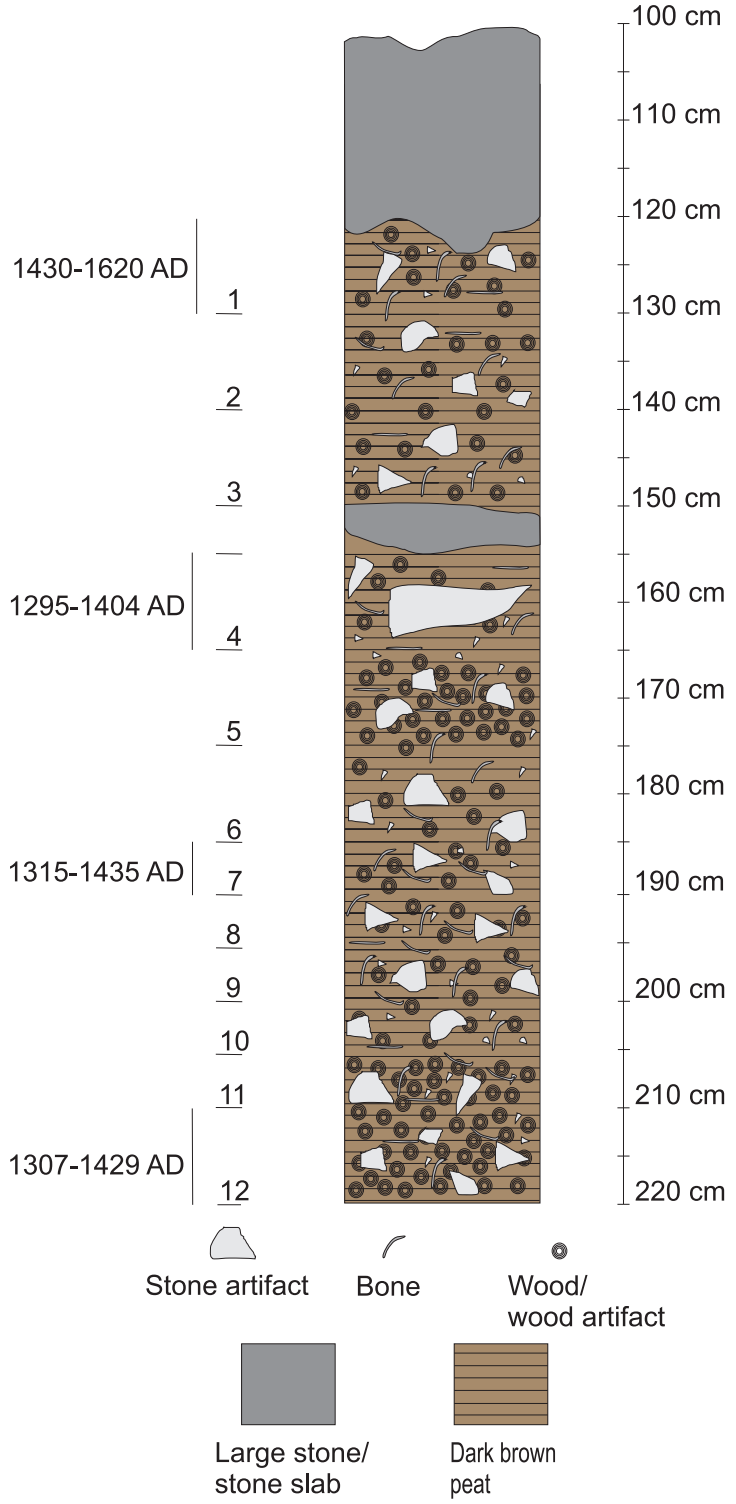

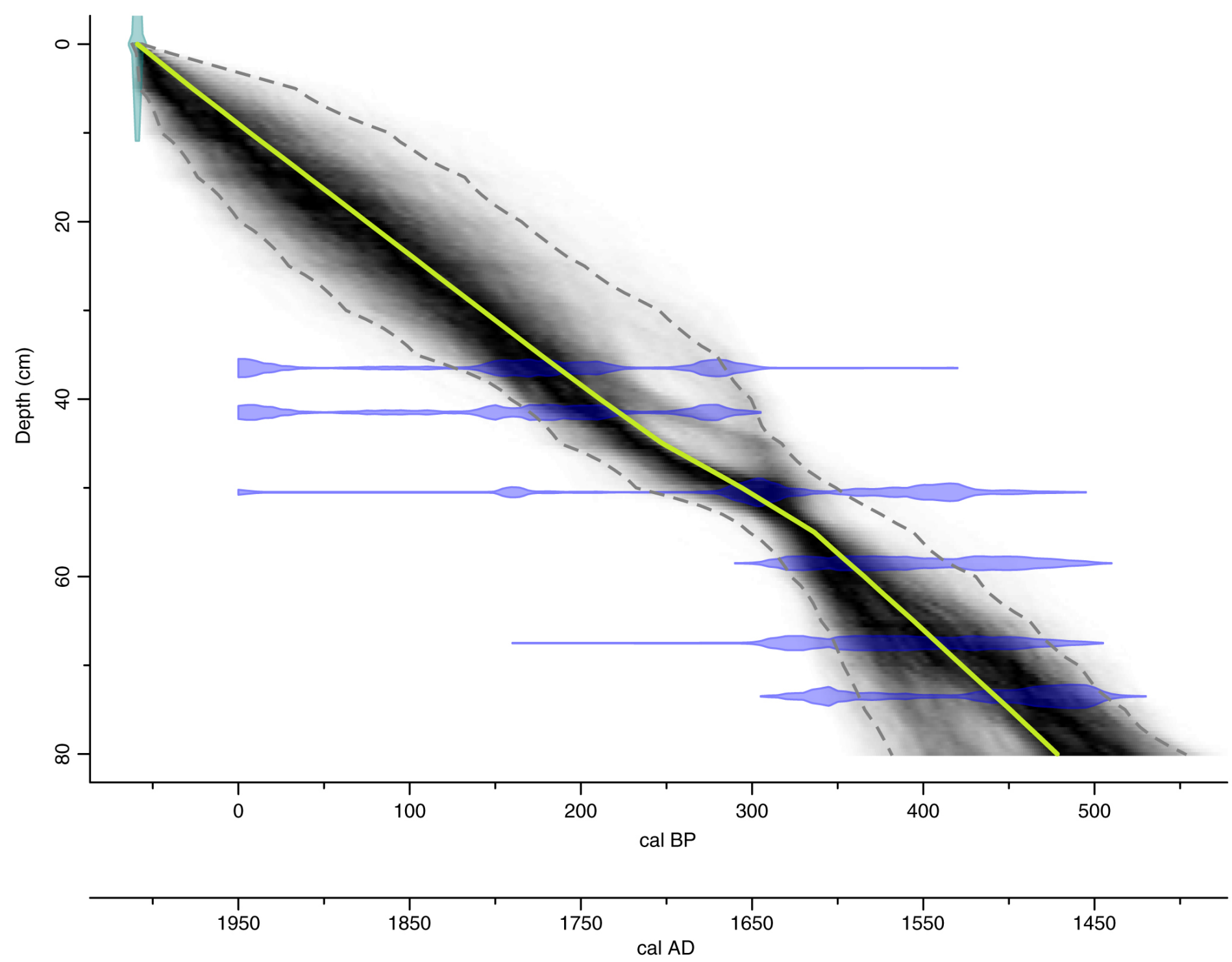


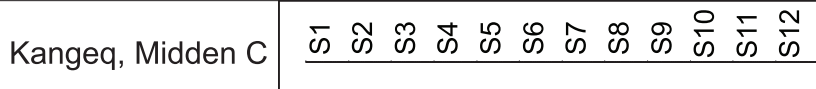

Aquatics

Standing water

Pasture/Dung

Meadowland

Wood and trees

Wetlands

/marshes

Open wet

habitats

Sandy/dry disturbed

Dung

/foul habitats

Mould beetles

Heathland

\& moorland

Halotolerant

SumRep

Abundance

NSpec

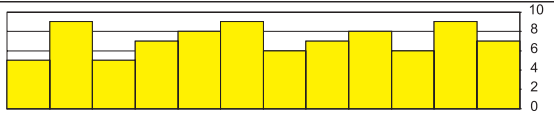


Kangeq, Midden C

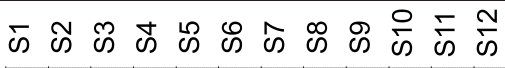

Haematophagous ectoparasites

Algaecolous

Endophilic coprophagus/ necrophagous

\section{Exophilic necrophagous}

Stercoricolous

Fucicolous+ algaecolous/ fucicolous

Abundance

NSpec

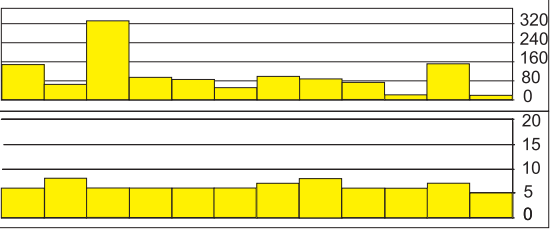




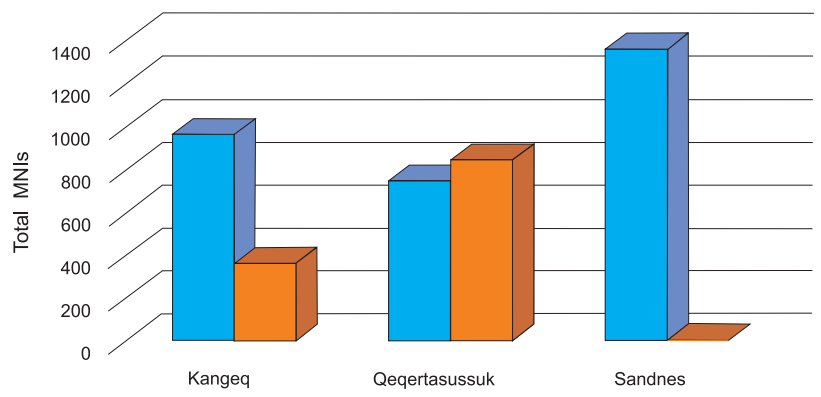

$\square$ Heleomyzidae $\quad \square$ Piophilidae 


\section{Spörer}

\section{Maunder}
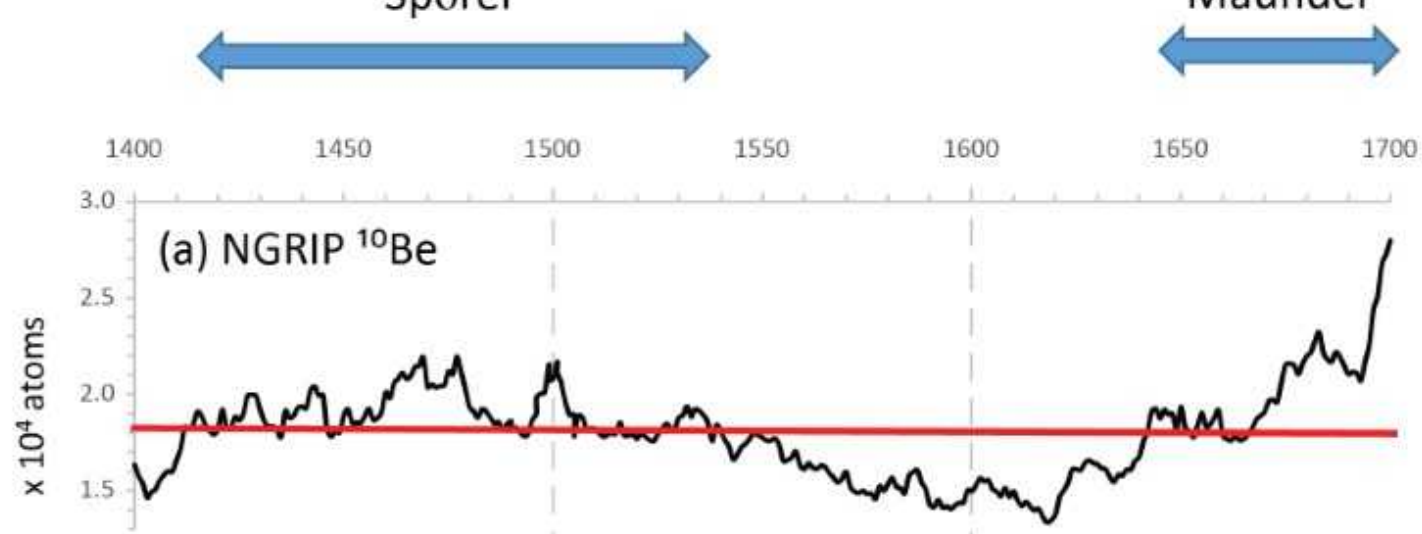

(b) NGRIP accumulation rate
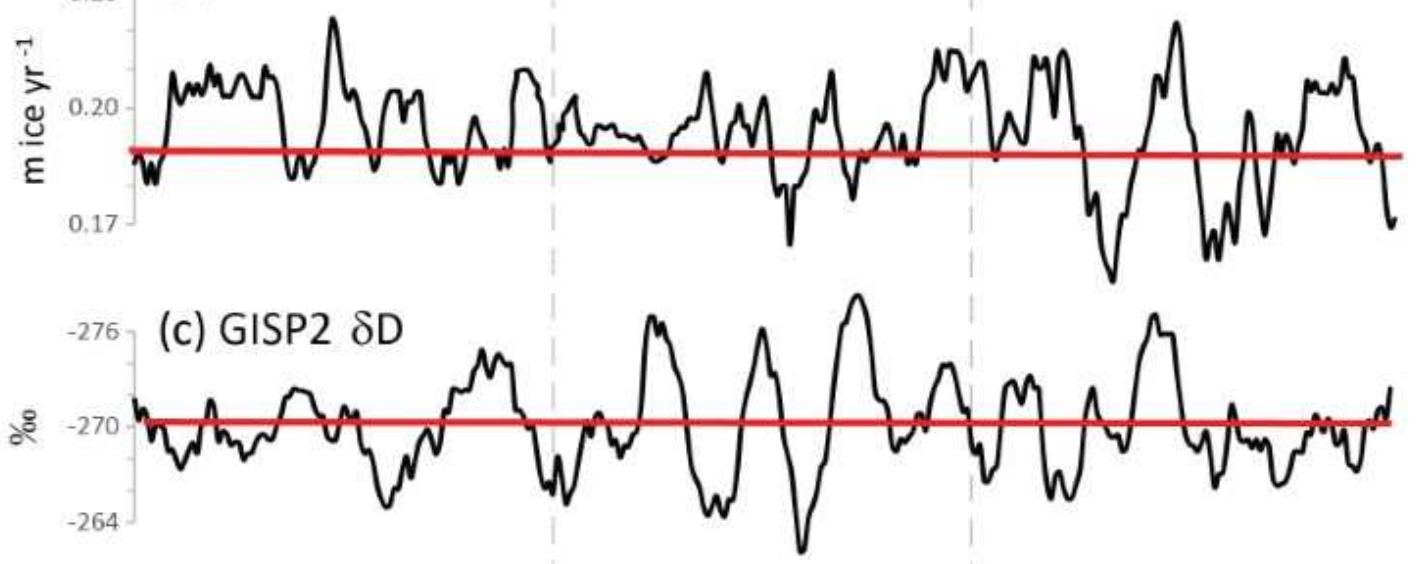

9 (d) Lake Braya Sø temperature
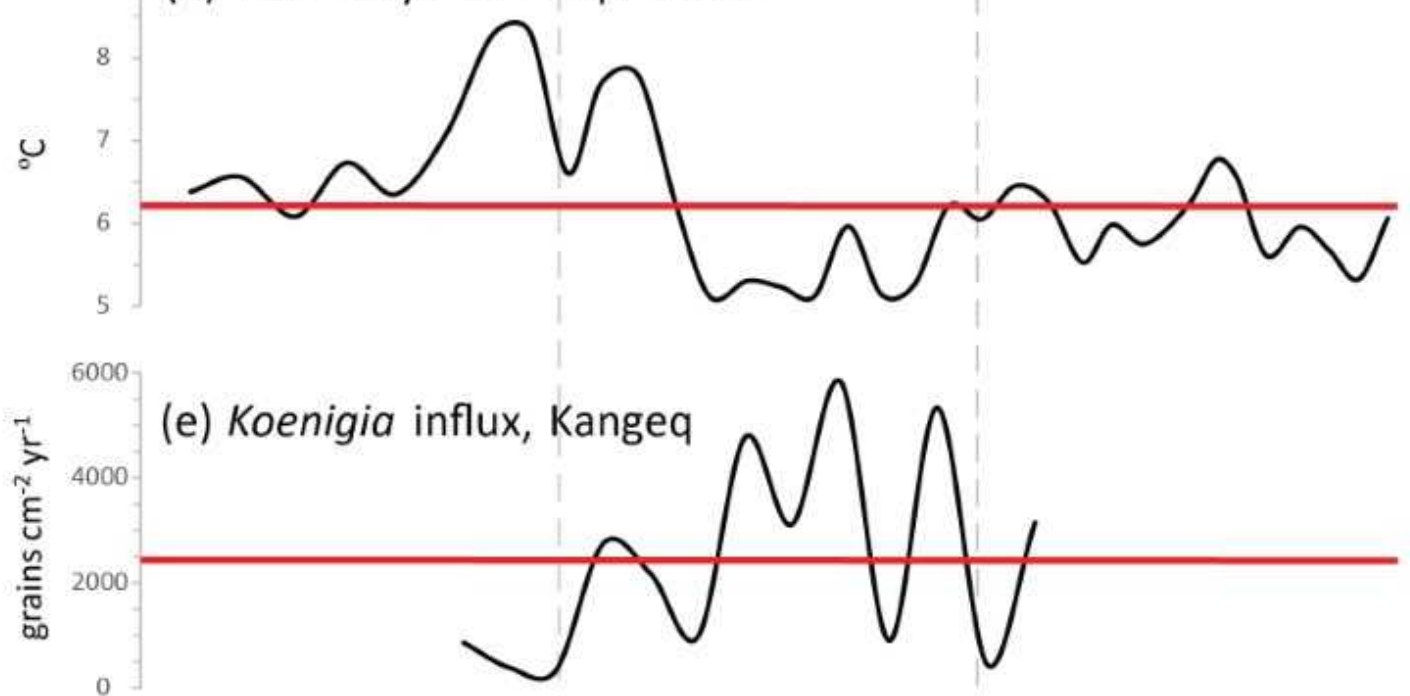

(f) Shrub pollen influx, Kangeq

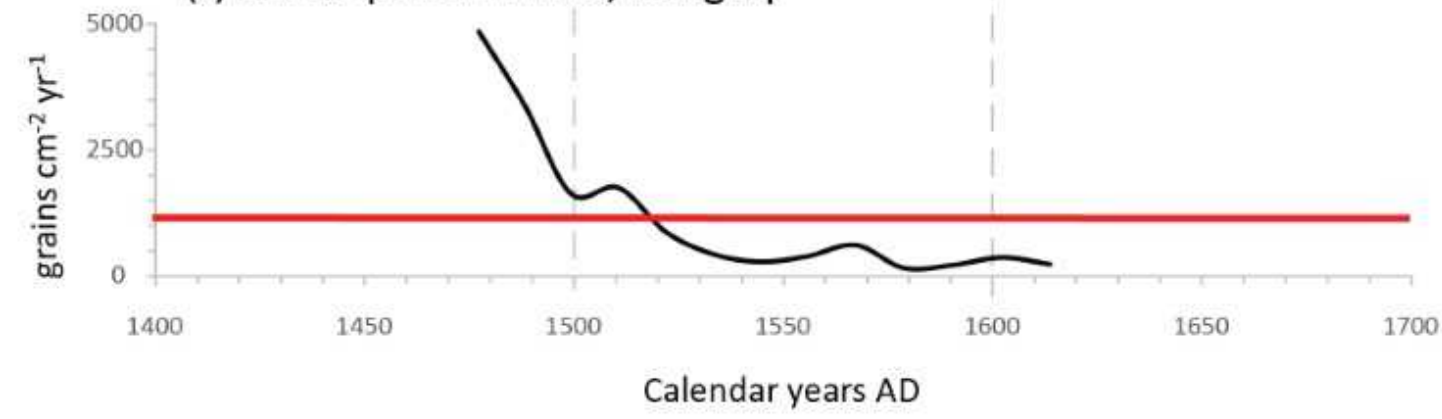




\begin{tabular}{|c|c|c|c|c|c|c|c|c|c|c|c|c|c|}
\hline Taxon & C-S1 & C-S2 & $\mathrm{C}-\mathrm{S3}$ & C-S4 & C-S5 & C-S6 & C-S7 & C-S8 & C-S9 & $\begin{array}{l}\text { C- } \\
\text { S10 }\end{array}$ & C-S11 & C-S12 & A-S1 \\
\hline $\begin{array}{l}\text { Depth in cm } \\
\text { (from } 120 \mathrm{~cm})\end{array}$ & $0-10$ & $10-20$ & $20-30$ & $35-45$ & $\begin{array}{l}45- \\
55\end{array}$ & $\begin{array}{l}55- \\
65 \\
\end{array}$ & $65-70$ & $\begin{array}{l}70- \\
75\end{array}$ & $\begin{array}{l}75- \\
80\end{array}$ & $\begin{array}{l}80- \\
85\end{array}$ & $85-90$ & $90-100$ & \\
\hline${ }^{{ }^{4} \mathrm{C} \text { dates }}$ & $\begin{array}{l}\mathrm{AD} \\
1430- \\
1620 \\
\end{array}$ & & & $\begin{array}{l}\mathrm{AD} \\
1295- \\
1404 \\
\end{array}$ & & & $\begin{array}{l}\mathrm{AD} \\
1315- \\
1435 \\
\end{array}$ & & & & & $\begin{array}{l}\mathrm{AD} \\
1304- \\
1423 \\
\end{array}$ & $\begin{array}{l}\mathrm{AD} \\
1307- \\
1429 \\
\end{array}$ \\
\hline \multicolumn{14}{|l|}{ Taxa } \\
\hline \multicolumn{14}{|l|}{ Coleoptera } \\
\hline \multicolumn{14}{|l|}{ Dytiscidae } \\
\hline Hydroporus morio Aubé & 1 & 1 & 1 & 2 & 5 & & & & & 1 & 1 & 1 & \\
\hline $\begin{array}{l}\text { Colymbetes dolabratus } \\
\text { (Payk.) }\end{array}$ & & & & & & & 1 & & 1 & & & 1 & \\
\hline \multicolumn{14}{|l|}{ Staphylinidae } \\
\hline Micralymma brevilingue Sch. & 310 & 199 & 263 & 226 & 240 & 343 & 261 & 187 & 250 & 212 & 201 & 150 & 137 \\
\hline Quedius fellmanni (Zett.) & & & & & & & & & & & 1 & & \\
\hline $\begin{array}{l}\text { Boreophilia hyperborea } \\
\text { Brundin }\end{array}$ & & 4 & & 3 & 1 & 11 & 8 & 6 & 1 & 1 & 9 & & 1 \\
\hline Aleocharinae indet. & 6 & 1 & & 3 & 5 & 22 & 3 & 1 & & & 1 & 1 & \\
\hline \multicolumn{14}{|l|}{ Byrrhidae } \\
\hline $\begin{array}{l}\text { Simplocaria metallica } \\
\text { (Sturm) }\end{array}$ & & 3 & & & & 2 & & & & & & & \\
\hline Simplocaria elongata Sahl. & & 2 & & & & 2 & & & 1 & & & & \\
\hline $\begin{array}{l}\text { Simplocaria } \\
\text { metallica/elongata } \\
\text { Sturm/Sahl. }\end{array}$ & & & & & & & & 1 & & & & & \\
\hline Byrrhus fasciatus (Forst.) & 1 & & 1 & 1 & 1 & 1 & & & 2 & & 1 & & \\
\hline \multicolumn{14}{|l|}{ Latridiidae } \\
\hline Corticaria linearis (Payk.) & & & & & & 1 & & & & & & & 1 \\
\hline \multicolumn{14}{|l|}{ Curculionidae } \\
\hline $\begin{array}{l}\text { Otiorhynchus arcticus (O. } \\
\text { Fabricius) }\end{array}$ & & & & & 2 & & & & & & & & \\
\hline $\begin{array}{l}\text { Otiorhynchus nodosus } \\
\text { (Müll.) }\end{array}$ & & 2 & 3 & 2 & 1 & 2 & 2 & 2 & 2 & 1 & 1 & 2 & \\
\hline Dorytomus imbecillus Faust & 1 & 1 & 1 & 1 & 1 & 1 & 1 & 1 & 1 & 1 & 1 & 1 & 1 \\
\hline $\begin{array}{l}\text { Hypera diversipunctata } \\
\text { Schrank }\end{array}$ & & 1 & 1 & & & & & 1 & 1 & 1 & 2 & 1 & \\
\hline \multicolumn{14}{|l|}{ Pthiraptera } \\
\hline \multicolumn{14}{|l|}{ Menoponidae } \\
\hline $\begin{array}{l}\text { Actornithophilus cf. } \\
\text { uniseriatus } \text { Pg. }\end{array}$ & & & & & & & & & & & 1 & & \\
\hline \multicolumn{14}{|l|}{ Ricinidae } \\
\hline Ricinus spp. & & & & & & & & & & 2 & & & \\
\hline \multicolumn{14}{|l|}{ Diptera } \\
\hline \multicolumn{14}{|l|}{ Simuliidae } \\
\hline Simulium sp. & & 1 & & & & & & & & 1 & & & \\
\hline \multicolumn{14}{|l|}{ Ephydridae } \\
\hline Scatella cf. stagnalis Fall. & 7 & 2 & 24 & 13 & 16 & 4 & 3 & 6 & 3 & 5 & 19 & 0 & 0 \\
\hline
\end{tabular}




\begin{tabular}{|c|c|c|c|c|c|c|c|c|c|c|c|c|c|}
\hline \multicolumn{14}{|l|}{ Heleomyzidae } \\
\hline Heleomyza borealis Bohe. & 58 & 7 & 186 & 28 & 13 & 7 & 22 & 29 & 6 & 5 & 75 & 9 & 17 \\
\hline Heleomyzidae indet. & 3 & & 8 & 3 & & & & 2 & & & 4 & & \\
\hline \multicolumn{14}{|l|}{ Piophilidae } \\
\hline Parapiophila vulgaris (Fall.) & 29 & 15 & 35 & 14 & 21 & 7 & 10 & 16 & 10 & 3 & 5 & 2 & 16 \\
\hline Piophilidae indet. & 1 & 0 & 0 & 3 & 0 & 1 & 1 & 0 & 1 & 0 & 1 & 1 & 0 \\
\hline \multicolumn{14}{|l|}{ Calliphoridae } \\
\hline Calliphora sp. & & & & & & & & & & & 1 & & \\
\hline \multicolumn{14}{|l|}{ Scathophagidae } \\
\hline Scathophaga furcata Say & 1 & 1 & 3 & 2 & 3 & 0 & 7 & 6 & 1 & & 20 & 1 & 1 \\
\hline Scathophaga sp. & & & & & & & 3 & 2 & & & & & \\
\hline \multicolumn{14}{|l|}{ Anthomyiidae } \\
\hline Fucellia sp. & & 14 & & & & & & & & & & & 9 \\
\hline Anthomyiidae indet. & 24 & 14 & 21 & 16 & 18 & 23 & 36 & 11 & 36 & 1 & & 2 & 9 \\
\hline \multicolumn{14}{|l|}{ Fanniidae } \\
\hline Fannia sp. & & & & & & & & 1 & & & & & \\
\hline Arachnidae indet. & & & & & & & & & & 1 & 2 & & \\
\hline Acarina & & & & & & & & & & 5 & 5 & & \\
\hline Trichoptera indet. & 1 & & 6 & 4 & 5 & 3 & 3 & 4 & & 1 & 2 & 2 & \\
\hline
\end{tabular}




\begin{tabular}{|c|c|c|c|c|c|}
\hline $\begin{array}{l}\text { Depth } \\
\text { (cm) }\end{array}$ & Lab code & Material & $\begin{array}{l}\text { Radiocarbon } \\
\text { age }\left({ }^{14} \mathrm{C} \text { yr }\right. \\
\mathrm{BP} \pm 1 \sigma) \\
\end{array}$ & $\begin{array}{l}\text { Cal. AD } \\
\text { range } \\
( \pm 2 \sigma) \\
\end{array}$ & $\begin{array}{l}\delta 13 C \\
(\%)\end{array}$ \\
\hline \multicolumn{6}{|c|}{ Pollen Core } \\
\hline $36-37$ & $\begin{array}{l}\text { SUERC- } \\
29239 \\
\end{array}$ & $\begin{array}{l}\text { Calliergon cordifolium } \\
\text { (Hedw.) Kindb. }\end{array}$ & $195 \pm 30$ & $\begin{array}{l}1650- \\
1950\end{array}$ & -21.7 \\
\hline $41-42$ & $\begin{array}{l}\text { SUERC- } \\
29240\end{array}$ & $\begin{array}{l}\text { Calliergon cordifolium } \\
\text { (Hedw.) Kindb. } \\
\text { and Sphagnum sect. } \\
\text { Squarrosa }\end{array}$ & $180 \pm 30$ & $\begin{array}{l}1655- \\
1950\end{array}$ & -21.1 \\
\hline $50-51$ & $\begin{array}{l}\text { SUERC- } \\
38435\end{array}$ & $\begin{array}{l}\text { Calliergon cordifolium } \\
\text { (Hedw.) Kindb. } \\
\text { and Drepanocladus } \\
\text { aduncus (Hedw.) Warnst. }\end{array}$ & $270 \pm 30$ & $\begin{array}{l}1515- \\
1950\end{array}$ & -20.1 \\
\hline $58-59$ & $\begin{array}{l}\text { SUERC- } \\
29244 \\
\end{array}$ & $\begin{array}{l}\text { Calliergon cordifolium } \\
\text { (Hedw.) Kindb. }\end{array}$ & $340 \pm 30$ & $\begin{array}{l}1470- \\
1639 \\
\end{array}$ & -22.6 \\
\hline $67-68$ & $\begin{array}{l}\text { SUERC- } \\
38436\end{array}$ & $\begin{array}{l}\text { Calliergon cordifolium } \\
\text { (Hedw.) Kindb. }\end{array}$ & $330 \pm 30$ & $\begin{array}{l}1480- \\
1640 \\
\end{array}$ & -21.8 \\
\hline $73-74$ & $\begin{array}{l}\text { SUERC- } \\
38437\end{array}$ & $\begin{array}{l}\text { Drepanocladus } \\
\text { exannulatus (Schimp.) } \\
\text { Warnst. }\end{array}$ & $390 \pm 30$ & $\begin{array}{l}1440- \\
1630\end{array}$ & -23.6 \\
\hline \multicolumn{6}{|c|}{ Middens } \\
\hline $\begin{array}{l}\text { C-S1 } \\
(0-10)\end{array}$ & $\begin{array}{l}\text { SUERC- } \\
31016\end{array}$ & Empetrum nigrum L. & $410 \pm 30$ & $\begin{array}{l}1430- \\
1620 \\
\end{array}$ & -24.9 \\
\hline $\begin{array}{l}\text { C-S4 } \\
(35-45)\end{array}$ & $\begin{array}{l}\text { SUERC- } \\
31017\end{array}$ & Empetrum nigrum L. & $610 \pm 30$ & $\begin{array}{l}1295- \\
1404\end{array}$ & -24.8 \\
\hline $\begin{array}{l}\text { C-S7 } \\
(65-70)\end{array}$ & $\begin{array}{l}\text { SUERC- } \\
31018\end{array}$ & Empetrum nigrum L. & $545 \pm 30$ & $\begin{array}{l}1315- \\
1435 \\
\end{array}$ & -24.4 \\
\hline $\begin{array}{l}\mathrm{C}-\mathrm{S} 12 \\
(90- \\
100) \\
\end{array}$ & $\begin{array}{l}\text { SUERC- } \\
31019\end{array}$ & Empetrum nigrum L. & $570 \pm 30$ & $\begin{array}{l}1305- \\
1423 \\
\end{array}$ & -24.7 \\
\hline A-S1 & $\begin{array}{l}\text { SUERC- } \\
31020\end{array}$ & Empetrum nigrum L. & $560 \pm 30$ & $\begin{array}{l}1305- \\
1430\end{array}$ & -24.7 \\
\hline
\end{tabular}

